\title{
Effect of Temperature and Germania on the Performance of Germania Doped Silica Fiber Raman Scattering Amplifier
}

B. M. El-den ( $\sim$ basant_moheyelden@yahoo.com )

Delta University for Science and Technology

Adel zaghloul

Delta University for Science and Technology - College of Engineering - Dept. of Communications \& Computer

\section{Research Article}

Keywords: Stimulated Raman Scattering (SRS), threshold pump power (Ppthr), saturation gain (Gs), Germania doped silica fiber, effective length (Leff), forward pump, backward pump

Posted Date: January 10th, 2022

DOI: https://doi.org/10.21203/rs.3.rs-1236592/v1

License: (c) (i) This work is licensed under a Creative Commons Attribution 4.0 International License. Read Full License 


\title{
Effect of Temperature and Germania on the Performance of Germania Doped Silica Fiber Raman Scattering Amplifier \\ B. M. El-den ${ }^{1}$,Adel zaghloul ${ }^{2}$ \\ 1 Communication Dep. Fuclty of engneering, Delta University , Gamasa city , Egypt \\ Corresponding Author: basant.mohyelden@deltauniv.edu.eg \\ 2 Delta University for Science and Technology - College of Engineering - Dept. of Communications \& Computer \\ (Total mandate to work from College of Engineering - Zagazig University, Egypt) \\ adel.zaghloul@deltauniv.edu.eg
}

\begin{abstract}
The Raman gain coefficient, the attenuations at signal and pump wavelengths and the refractive indices of both core and cladding of silica doped Germania optical fiber are functions of the Germania ratio, temperature and wavelengths. The Raman amplifier gain increases with Germania ratio but it decreases with temperature. Also, Raman gain either increases or decreases with signal wavelength. As the fiber core radius increases, the Raman gain decreases.
\end{abstract}

The gain distribution through the amplifier length of dual pumps with power divided ratio $(S=0.5)$ is better than that for the forward pump amplifier and the backward pump amplifier. The forward pump has a maximized gain but the backward pump has a minimized gain, while the dual pumps have both the maximum and minimized gains. The final amplifier gain for the three kinds of pumps with the same pump power $\left(\mathrm{P}_{\mathrm{p}}\right)$ is equally.

The pump wavelength $\left(\lambda_{\mathrm{p}}=1.4553 \mu \mathrm{m}\right)$ gives the biggest Raman gain at the center of wideband signal wavelength $\left(\lambda_{\mathrm{s}}=1.50\right.$ to $\left.1.60 \mu \mathrm{m}\right)$. With $\lambda_{\mathrm{p}}=1.48 \mu \mathrm{m}$, the gain increases with $\lambda_{\mathrm{s}}$ until $\lambda_{\mathrm{s}}=1.57 \mu \mathrm{m}$ and after that the gain decreases with $\lambda_{\mathrm{s}}$ and so with the above three kinds of pumps, gain fluctuations over the band wavelength of signal. The threshold pump power and gain saturation are studied.

Keyword's: Stimulated Raman Scattering (SRS), threshold pump power $\left(\mathrm{P}_{\text {pthr }}\right)$, saturation gain $\left(\mathrm{G}_{\mathrm{s}}\right)$, Germania doped silica fiber, effective length ( $L_{\text {eff }}$, , forward pump , backward pump.

\section{Introduction}

Raman amplifier is widely used with optical telecommunication systems [1]. Raman gain occurs by transfer of power from optical pump (which has power, $\mathrm{Pp}$, and wavelength, $\lambda \mathrm{p}$ ) to the optical signal (which has power, Ps, and wavelength, $\lambda s$, where $\lambda p<\lambda s$ ) [2]. Nonlinear effect requires an optical power higher than a threshold pump power (Ppthr) [1]. The telecommunications bands are around $1500 \mathrm{~nm}(13.2 \mathrm{THz})$ corresponds to approximately $100 \mathrm{~nm}(40 \mathrm{THz})$ [2]. GeO2 molecules exhibit a larger Raman gain peaking near 13.1 THz [3]. The Raman scattering effect constitutes one of the basic physical mechanisms exploited in optical fiber distributed temperature sensing.[4].

The signal attenuation coefficient ( $\alpha_{\mathrm{s}}$ at signal wavelength, $\lambda_{\mathrm{s}}$ ) and the pump attenuation coefficient ( $\alpha_{\mathrm{p}}$, at pump wavelength, $\left.\lambda_{\mathrm{p}}\right)$ are increasing with Germania ratio $\left(\mathrm{x}_{1}\right)$ and temperature $(\mathrm{T})$. The minimum attenuation coefficient of Germania doped silica fiber $\left(\alpha_{\min }\right.$ occurs at $\lambda_{\alpha}$ min, around $\left.1.55 \mu \mathrm{m}\right)$ is crawling apart from $\lambda=1.5 \mu \mathrm{m}$ with increasing $T$ and $x_{1}$. The value of $\alpha_{p}$ decreasing with increasing $\lambda_{p}$ because of $\lambda_{p}$ usually less than $\lambda_{\alpha \text { min. }}$. The attenuation $\left(\mathrm{A}_{\mathrm{tt}}\right)$ increases with $\mathrm{x}_{1}, \mathrm{~T}$ and $\mathrm{L}$.

The Raman gain coefficient $\left(\mathrm{g}_{\mathrm{rx} T}\right)$ increases with $\mathrm{x}_{1}$ but it decreases with $\mathrm{T}$. The effective Raman length ( $\left.\mathrm{L}_{\text {eff }}\right)$ decreases with $\mathrm{x}_{1}$ and $\mathrm{T}$ but it increases with the amplifier length $(\mathrm{L})$. Therefore, for the same net gain, as $\mathrm{g}_{\mathrm{rxt}}$ increases, the required $\mathrm{L}$ decreases. The gain becomes more with $\mathrm{x}_{1}$ while in the other side, the value of the allowable core radius (a) becomes little than the required value for telecommunications. Also, more $\mathrm{x}_{1}$ gives best power launched into fiber.

The net Raman amplifier gain $(\mathrm{G} \mathrm{db})$ decreases linearly with the product $\alpha_{s} \mathrm{~L}$ but $\mathrm{G}$ increases linearly with the product of $\left(\mathrm{g}_{\mathrm{rxx}} \mathrm{L}_{\mathrm{eff}}\right)$ until the gain saturation $(\mathrm{G})$. Therefore, $\mathrm{G}$ increases with $\mathrm{x}_{1}$ but $\mathrm{G}$ decreases with $\mathrm{T}$. As the effective fiber core area $\left(A_{\text {eff }}\right)$ increases, the value of $g_{r x T}$ decreases. The value of $A_{\text {eff }}$ increase with $\lambda_{s}$ and $\lambda_{p}$ while it decreases with $\mathrm{x}_{1}$ and $\mathrm{T}$.

The final Raman gain with the three kinds of bumps (forward pump, $\mathrm{G}_{\mathrm{F}}$, backward pump, $\mathrm{G}_{\mathrm{B}}$, and dual pumps, $\mathrm{G}_{\mathrm{D}}$ ) are equally. The Raman gain distribution with dual pumps, $\mathrm{G}_{\mathrm{D}}(\mathrm{z})$, is better than that with forward pump, $D_{\mathrm{F}}(\mathrm{z})$ or backward pump, $\mathrm{G}_{\mathrm{B}}(\mathrm{z})$ (especially with divided pump power factor, $\mathrm{S}=0.5$ ). With forward pump, there is a maximum gain $\left(\mathrm{G}_{\mathrm{Fmax}}\right.$ which occurs at $\mathrm{Z}_{\mathrm{Fmax}}$ ) but with backward pump, there is a minimum gain $\left(\mathrm{G}_{\mathrm{Bmin}}\right.$ which occurs at $\left.Z_{\mathrm{Bmin}}\right)$, while with dual pumps, there are both maximum gain $\left(\mathrm{G}_{\mathrm{Dmax}}\right.$ which occurs at $\left.Z_{\mathrm{Dmax}}\right)$ and minimum gain $\left(\mathrm{G}_{\mathrm{Dmin}}\right.$ which occurs at $\left.\mathrm{Z}_{\mathrm{Dmin}}\right)$. The power transferred between lower signal wavelengths to higher signal wavelengths due to the stimulated Raman scattering is neglected. 
In this study, the Raman amplifier is analyzed with temperature range ( $\mathrm{T}=-20$ to $\left.60^{\circ} \mathrm{C}\right)$, signal wavelength range $\left(\lambda_{\mathrm{s}}=1.50\right.$ to $\left.1.60 \mu \mathrm{m}\right)$, pump wavelength $\left(\lambda_{\mathrm{p}}=1.45\right.$ to $\left.1.49 \mu \mathrm{m}\right)$ and Germania ratio $\left(\mathrm{x}_{1}=0.03\right.$ to 0.05$)$. To operate the optical fiber as a single mode during the last ranges of $\mathrm{T}, \mathrm{x}_{1}$ and $\lambda_{\mathrm{s}}$, the allowable core radius (a) ranges between $a=3.36$ to $3.74 \mu \mathrm{m}$ (simulation results is calculated with $\mathrm{a}=3.5 \mu \mathrm{m}$ ). The simulation results are done for the three kinds of pumps.

\section{II- Mathematical Analysis}

\section{II.1 Effect of $T$ and $x_{1}$ on the refractive indices ( $n_{1}$ and $n_{2}$ ), effective core area ( $\left.A_{e f f}\right)$ and attenuations ( $\alpha_{s}$ and $\left.\alpha_{p}\right)$ of a single mode fiber.}

The refractive indices of core (silica doped Germania, $\mathrm{n}_{1}$ ) and clad (pure silica, $\mathrm{n}_{2}$ ) materials are increases with both temperature $\left(\mathrm{T}^{\circ} \mathrm{K}\right)$ and Germania ratio $\left(\mathrm{x}_{1}\right)$ while they are decreases with wavelength $\left(\lambda_{\mu \mathrm{m}}\right)$ as explained in Appendix A.

Effective fiber core area $\left(\mathrm{A}_{\mathrm{eff}}\right)$ is defined as [5]

$$
A_{\text {eff }}=\frac{1}{2}\left(A_{s}+A_{p}\right)=\frac{\pi}{2}\left(W_{s}^{2}+W_{p}^{2}\right)
$$

Where, $A_{s}$ is the effective cross section area of the optical fiber at signal wavelength $\left(\lambda_{s}\right), A_{p}$ is the effective cross section area of the fiber at optical pump wavelength $\left(\lambda_{\mathrm{p}}\right), \mathrm{W}_{\mathrm{s}}$ is the effective core radius at signal wavelength and $\mathrm{W}_{\mathrm{p}}$ is the effective core radius at pump wavelength. $\mathrm{W}_{\mathrm{s}, \mathrm{p}}$ is defined as [6];

$$
W_{s, p}=0.65+\frac{1.619}{V_{s, p}^{1.5}}+\frac{2.879}{V_{s, p}^{6}}
$$

Where $V_{s}$ and $V_{p}$ are the normalized frequencies of fiber at $\lambda_{s}$ and $\lambda_{p}$, respectively.

As expected, the value of normalized frequency $\left\{\mathrm{V}=(2 \pi \mathrm{a} / \lambda)\left(\mathrm{n}^{2}{ }_{1}-\mathrm{n}^{2}{ }_{2}\right)^{0} .5[6]\right\}$ increases with $\mathrm{x}_{1}$ but $\mathrm{V}$ decreases with both $\mathrm{T}$ and $\lambda$ as indicated in Fig.1. a.

The value of $A_{s}$ usually greater than the value of $A_{p}$, because of the value of $\lambda_{s}$ must be greater than that the value of $\lambda_{\mathrm{p}}$. Also, the value of $A_{\text {eff }}$ increases with increasing both $\lambda_{p}$ and $\lambda_{s}$. But $A_{\text {eff }}$ decreases with increasing the Germania ratio $\left(x_{1}\right)$ as shown in Fig.1.b (where the values of $V_{s}$ and $V_{p}$ are increased with $x_{1}$ as shown in Fig.1.a, so more optical confinement). Also, Aff $_{\text {ef }}$ decreases with higher temperature as shown in Fig.1. b.

The attenuation of optical through Germania doped silica fiber $\left(\alpha_{1}\right)$ is a function of $x_{1}, \lambda$ and T as defined in [7];

$$
\alpha_{1}=0.003+\frac{0.75+66 \Delta}{\lambda^{4}} \frac{T}{T_{0}}+7.81 * 10^{11} e^{-48.48 / \lambda}+\frac{1.542 x_{1} e^{4.63 / \lambda}}{60+46.6 x_{1}}
$$

$(\mathrm{db} / \mathrm{km})$

Where $\Delta$ is the relative refractive index difference $\{2 \Delta=1-\mathrm{n} 22 / \mathrm{n} 21$ [6] $\}$ and To is the reference temperature $\left(\mathrm{T}_{\mathrm{o}}=300^{\circ} \mathrm{K}\right)$. Note, $\alpha\left(\right.$ in $\left.\mathrm{km}^{-1}\right)=0.2303 \alpha_{1} \quad$ (in $\left.\mathrm{db} / \mathrm{km}\right)$.

For Germania doped silica fiber, there is minimum value of attenuation $\left(\alpha_{\min }\right)$ which occurs at wavelength ( $\left.\lambda_{\text {amin }}\right)$. Both the values of $\alpha_{\min }$ and $\lambda_{\text {amin }}$ are increasing with the doping ratio $\left(x_{1}\right)$ as shown in Fig. 1. c. The value of $\lambda_{\alpha \text { min }}$ occurs around $1.55 \mu \mathrm{m}$.

So, the signal attenuation $\left(\alpha_{\mathrm{s} 1} \mathrm{db} / \mathrm{km}\right)$ decreases with $\lambda_{\mathrm{s}}<\lambda_{\text {amin }}$ while, $\alpha_{\mathrm{s} 1}$ increases with $\quad \lambda_{\mathrm{s}}>\lambda_{\text {amin }}$ as shown in Fig.1. c. While, the pump attenuation $\left(\alpha_{\mathrm{p} 1 \mathrm{db}} / \mathrm{km}\right)$ decreases with increasing $\lambda_{\mathrm{p}}$ (where $\lambda_{\mathrm{p}}<\lambda_{\text {amin }}$ ). Both the values of $\alpha_{\mathrm{s} 1}$ and $\alpha_{\mathrm{p} 1}$ are increased with increasing the value of Germania $\left(\mathrm{x}_{1}\right)$ and temperature (T) as shown in Fig.1. c.

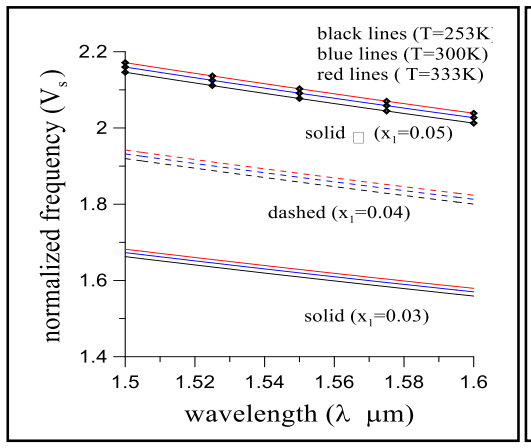

a) $\mathrm{V}_{\mathrm{s}}$ with $\mathrm{a}=3.5 \mu \mathrm{m}$

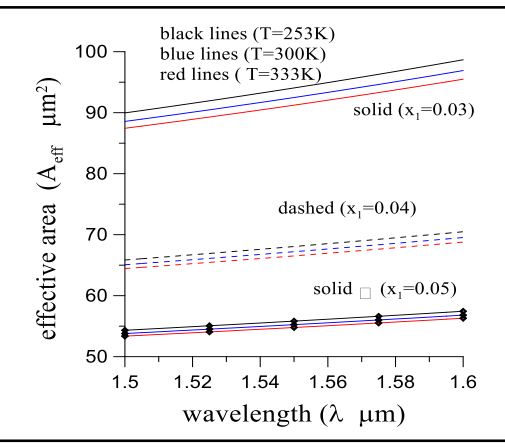

b) $\mathrm{A}_{\text {eff }}$ with $\left.\mathrm{a}=3.5 \mu \mathrm{mc}\right) \quad \alpha_{\mathrm{s} 1} \mathrm{db} / \mathrm{km}$

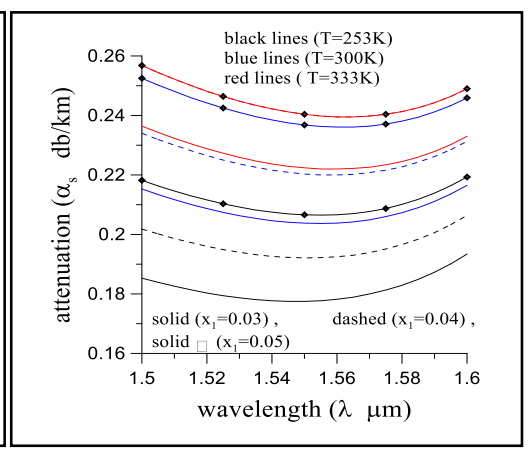

c) attenuation coefficient $\alpha_{\mathrm{s}}$

Fig.1 Effect of both temperature (T), Germania ratio $\left(\mathrm{x}_{1}\right)$ and the wavelength $(\lambda)$ on $\mathrm{V}_{\mathrm{s}}, \mathrm{A}_{\mathrm{eff}}$ and $\alpha_{\mathrm{s} 1}$ with $\mathrm{T}_{0}=300^{\circ} \mathrm{K}, \lambda_{\mathrm{p}}=1.48 \mu \mathrm{m}$ and $\mathrm{a}=3.5 \mu \mathrm{m}$ 


\section{II.2Effective Raman scattering length (Leff)}

Because of the pump absorption, the effective amplification length is reduced from the amplifier length (L) to the effective length $\left(\mathrm{L}_{\mathrm{eff}}\right)$. It is the distance that equates a distance during which the power is transferred from the pump to the signal. It is defined as [8]

$$
\mathrm{L}_{\text {eff }}=\left(1-\mathrm{e}^{-\alpha_{\mathrm{p}} \mathrm{L}}\right) / \alpha_{\mathrm{p}} \quad \mathrm{km} \quad\left(\text { where } \alpha_{\mathrm{p}} \text { in } \mathrm{km}^{-1}\right) .
$$

From Eq.3.a, the value of $\mathrm{L}_{\mathrm{eff}}$ increases with lowering $\alpha_{\mathrm{p}}$ as shown in Fig.2.a (so, $\mathrm{L}_{\mathrm{eff}}$ decreases with $\mathrm{T}$ and $\mathrm{x}_{1}$ as indicated in Fig.2.b). The attenuation $\alpha_{p}$ decreases with $\lambda_{p}$ (usually $\lambda_{p}<\lambda_{\text {amim }} ; \lambda_{\text {amim }}$ around $1.55 \mu \mathrm{m}$ ). So, the value of $\mathrm{L}_{\mathrm{eff}}$ increases with the pump wavelength $\left(\lambda_{\mathrm{p}}\right)$.

From Eq.3.a, the ratio ( $\left.\mathrm{L}_{\mathrm{eff}} / \mathrm{L}\right)$ versus the product $\left(\alpha_{\mathrm{p}} \mathrm{L}\right)$ is;

$$
\mathrm{L}_{\mathrm{eff}} / \mathrm{L}=\left(1-\mathrm{e}^{-\alpha_{\mathrm{p}} \mathrm{L}}\right) /\left(\alpha_{\mathrm{p}} \mathrm{L}\right) \ldots
$$

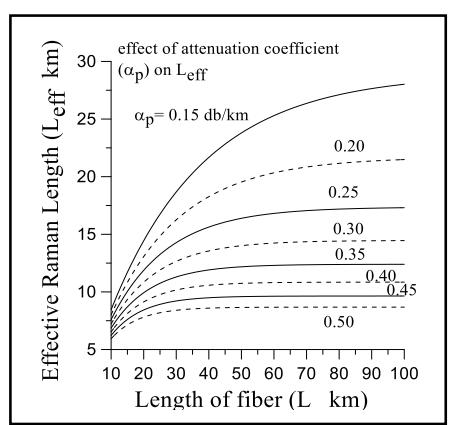

a) $L_{\text {eff }}$ versus $L$

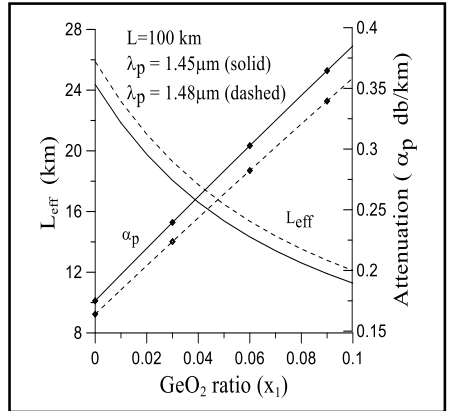

b) Leff versus $x_{1}$

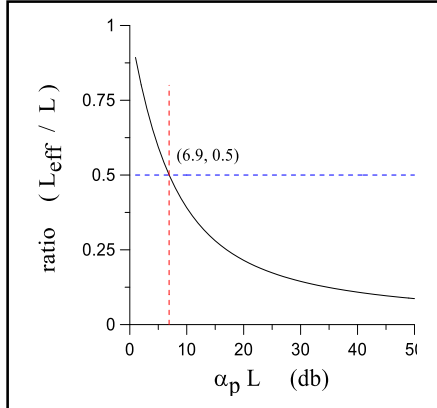

c) $\mathrm{L}_{\text {eff }} / \mathrm{L}$ versus $\alpha_{\mathrm{p}} \mathrm{L}$

Fig.2 Effective Raman scattering length ( $\left.\mathrm{L}_{\text {eff }}\right)$ versus both span length (L)and $\alpha_{\mathrm{p}}(\mathrm{db} / \mathrm{km})$ with $\left(\mathrm{T}_{0}=300^{\circ} \mathrm{K}\right), \lambda_{\mathrm{p}}=1.48 \mu \mathrm{m}, \mathrm{a}=3.5 \mu \mathrm{m}$

The value of $\mathrm{L}_{\text {eff }}$ becomes $0.5 \mathrm{~L}$ at $\alpha_{\mathrm{p}} \mathrm{L}=1.593$ (where $\alpha_{\mathrm{p}}$ in $\mathrm{km}^{-1}$ ) i.e. $\alpha_{\mathrm{p} 1} \mathrm{~L}=6.91$ (with $\alpha_{\mathrm{p} 1}$ in $\mathrm{db} / \mathrm{km}$, as shown in Fig.2.c). Therefore, with conventional value of $\alpha_{\mathrm{p}}=0.05152 \mathrm{~km}^{-1}$ (Note, with $\mathrm{x}_{1}=0.03, \mathrm{~T}=300^{\circ} \mathrm{K}$ and $\lambda=1.48 \mu \mathrm{m}$, the value of $\alpha_{\mathrm{pl}}=0.2238 \mathrm{db} / \mathrm{km}$, i.e., $\alpha_{\mathrm{p}}=0.05152 \mathrm{~km}^{-1}$ ), the corresponding values of $\mathrm{L}=30.92 \mathrm{~km}$ and $\mathrm{L}_{\mathrm{eff}}=15.46 \mathrm{~km}$. So, the dual pumps (forward and backward pumps) are used without fear of accumulation of the two pumps effective Raman scattering lengths where the Raman amplifier length usually greater than $100 \mathrm{~km}$ (where signal attenuation by some $20 \mathrm{~dB}$ makes it necessary to restore the power level by amplification [9]).

\section{II.3 Stimulated Raman scattering gain coefficient $\left(\mathrm{g}_{\mathrm{rxT}}\right)$}

Stimulated Raman scattering gain coefficient for pure silica, $g_{R 0}(\mathrm{~m} / \mathrm{W})$ is defined by using the published data which stated in [10] as shown in Fig.3 and the relation between $\mathrm{g}_{\mathrm{R} 0}$ and $\Delta \mathrm{k}_{\mathrm{ps}}$ (the modified wave number difference) is derived in Appendix B.

Where, $\Delta \mathrm{k}_{\mathrm{ps}}$ is defined as;

$$
\Delta \mathrm{k}_{\mathrm{ps}}=10000\left(\frac{1}{\lambda_{\mathrm{p}}}-\frac{1}{\lambda_{\mathrm{s}}}\right) \quad \mathrm{cm}^{-1} \quad\left\{\text { with, } \lambda_{\mathrm{p}}(\mu \mathrm{m}) \text { and } \lambda_{\mathrm{s}}(\mu \mathrm{m})\right\} .
$$

So, for $\lambda_{\mathrm{s}}=1.5$ to $1.60 \mu \mathrm{m}$ and $\Delta \mathrm{k}_{\mathrm{ps}}=90$ to $584 \mathrm{~cm}^{-1}$ (optimum values of $\Delta \mathrm{k}_{\mathrm{ps}}$ ), the corresponding value of $\lambda_{\mathrm{p}}=1.48 \mu \mathrm{m}$.

For pure silica, the maximum Raman scattering gain $\mathrm{g}_{\mathrm{r} 0 \max }=0.65^{*} 10^{-13} \mathrm{~m} / \mathrm{W}[11]$ which it occurs at $\Delta \mathrm{kps}=420$ $\mathrm{cm}-1$ as shown in Fig.3. Therefore, with $\lambda \mathrm{p}=1.48 \mu \mathrm{m}$, the value of gr0max occurs at $\lambda \mathrm{s}=1.5781 \mu \mathrm{m}$.

The modified wavenumber difference $\left(\Delta \mathrm{k}_{\mathrm{ps}}\right)$ decreases with $\lambda_{\mathrm{p}}$ while $\Delta \mathrm{k}_{\mathrm{ps}}$ increases with $\lambda_{\mathrm{s}}$ as shown in Fig.4.

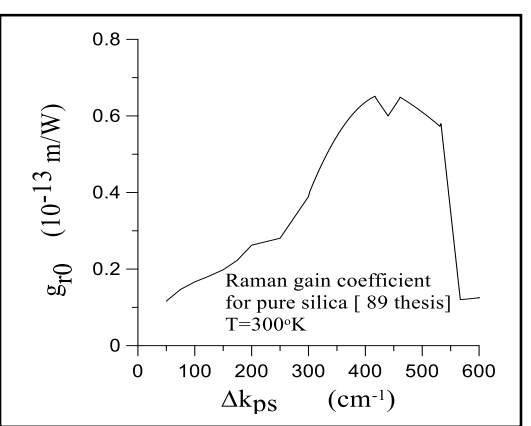

Fig.3 The value of $\mathrm{g}_{\mathrm{R} 0}$ versus $\Delta \mathrm{k}_{\mathrm{ps}}$ from [10]
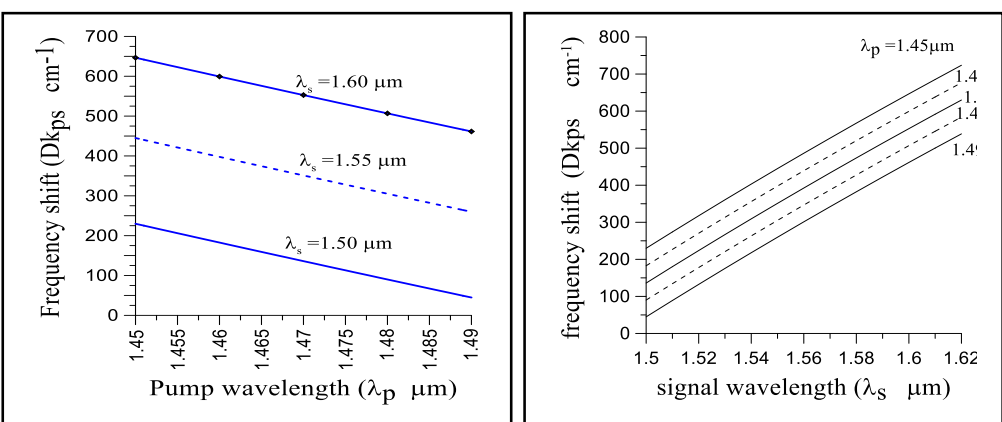

a) $\Delta \mathrm{k}_{\mathrm{ps}}$ versus $\lambda_{\mathrm{p}}$

b) $\Delta \mathrm{k}_{\mathrm{ps}}$ at different values of $\lambda_{\mathrm{p}}$

Fig.4 Effect of both $\lambda_{\mathrm{p}}$ and signal wavelength $\lambda_{\mathrm{s}}$ on $\left(\Delta \mathrm{k}_{\mathrm{ps}}\right)$ 
* The dependence of $\mathrm{g}_{\mathrm{r}}$ on the doping ratio $\left(\mathrm{x}_{1}\right)$ is [ 10];

$$
\mathrm{g}_{\mathrm{Rx}}=\frac{\mathrm{n}_{2}^{2}}{\mathrm{n}_{1}^{2}}\left\{\mathrm{~g}_{\mathrm{R} 0}+100 C_{v} \mathrm{x}_{1} \mathrm{~g}_{\mathrm{R} 0 \max } \frac{\lambda_{\mathrm{s}}^{3}}{\lambda_{\mathrm{smax}}^{3}}\right\} .
$$

Where, $\mathrm{g}_{\mathrm{R} 0 \max }$ is the maximum value of $\mathrm{g}_{\mathrm{R} 0}, \lambda_{\text {smax }}$ is the wavelength at which $\mathrm{g}_{\mathrm{R} 0}$ becomes $\mathrm{g}_{\mathrm{R} 0 \max }, \mathrm{n}_{1}$ and $\mathrm{n}_{2}$ are the refractive indices of core and clad respectively at $\lambda_{\mathrm{s}}$ and the parameter $\mathrm{C}_{\mathrm{v}}$ is defined in Appendix $\mathrm{C}$.

The value of $\mathrm{g}_{\mathrm{R} 0 \max }$ as a function of $\mathrm{x} 1$ is [12];

$$
\mathrm{g}_{\mathrm{Rxmax}}=\left(1+8.0 \mathrm{x}_{1}\right) \mathrm{g}_{\mathrm{R} 0 \max } \quad \text { (where } \mathrm{x}_{1} \text { ratio). }
$$

For silica, $g_{R 0 \max }$ occurs at $\Delta \mathrm{k}_{\mathrm{ps}}=420 \mathrm{~cm}^{-1}$, therefore from Eq.4.a,

$$
\lambda_{\text {smax }}=\left(\lambda_{\mathrm{p}}^{-1}+0.042\right)^{-1}
$$

* The temperature dependence of Raman scattering gain $\left(\mathrm{g}_{\mathrm{RxT}}\right)$ is derived from the relation between zero Kelvin Raman cross section of pure silica $\left(\sigma_{0}\right)$ and temperature $(\mathrm{T})$ which stated in [13]. So $\mathrm{g}_{\mathrm{RxT}}$ is derived as;

$$
g_{R x T}=g_{R x} T_{p 1}
$$

Where, $\mathrm{Tp}_{1}=\mathrm{T}_{\mathrm{p}} / \mathrm{T}_{\mathrm{p}(\mathrm{T}=300)}$ and $\mathrm{T}_{\mathrm{p}}$ is the thermal population factor $[4,14]$;

$$
T_{p}=1+\frac{1}{-1+\exp \left\{\mathrm{h}\left(\mathrm{f}_{\mathrm{p}}-\mathrm{f}_{\mathrm{s}}\right) / \mathrm{T} \mathrm{K}_{\mathrm{B}}\right\}}
$$

Where; $\mathrm{h}$ is the plank's constant $\left(\mathrm{h}=6.625^{*} 10^{-34} \mathrm{~J} . \mathrm{s}\right), \mathrm{T}$ is the temperature $\left(\mathrm{T}{ }^{\circ} \mathrm{K}\right)$ and $\mathrm{K}_{\mathrm{B}}$ is the Boltzmann constant $\left(\mathrm{K}_{\mathrm{B}}=1.38^{*} 10^{-23} \mathrm{~J} /{ }^{\circ} \mathrm{K}\right)$ and $\mathrm{f}_{\mathrm{p}}$ and $\mathrm{f}_{\mathrm{s}}$ are the pump and signal frequencies. So,

$$
T_{p}=1-\exp \left(-1.44 \Delta \mathrm{k}_{\mathrm{ps}} / \mathrm{T}\right)
$$

The temperature dependence of $\mathrm{T}_{\mathrm{p} 1}$ becomes little at higher values of $\Delta \mathrm{k}_{\mathrm{ps}}$ as shown in Fig. 5 . With $\Delta \mathrm{k}_{\mathrm{ps}}=90 \mathrm{~cm}^{-1}$ the value of $\mathrm{T}_{\mathrm{p} 1}$ decreases from 1.1427 (at $\mathrm{T}=253 \mathrm{~K}$ ) to 0.9190 (at $\mathrm{T}=333 \mathrm{~K}$ ), while with $\Delta \mathrm{k}_{\mathrm{ps}}=507 \mathrm{~cm}^{-1}$ the value of $\mathrm{T}_{\mathrm{p} 1}$ decreases from 1.0350 (at $\mathrm{T}=253 \mathrm{~K}$ ) to 0.9738 (at $\mathrm{T}=333 \mathrm{~K}$ ). From Fig.5 for $\mathrm{T}<300 \mathrm{~K}$, the value of $\mathrm{g}_{\mathrm{RxT}}$ becomes greater than that $\mathrm{g}_{\mathrm{RxT}}(\mathrm{T}=300 \mathrm{~K})$ and decreases with $\mathrm{T}$. But for $\mathrm{T}>300 \mathrm{~K}$, the value of $\mathrm{g}_{\mathrm{RxT}}$ becomes smaller than that $\mathrm{g}_{\mathrm{RxT}}(\mathrm{T}=300 \mathrm{~K})$ and decreases with $\mathrm{T}$. The final effective stimulated Raman scattering gain coefficient $\left(\mathrm{g}_{\mathrm{rxT}}\right)$ is defined as

$$
\mathrm{g}_{\mathrm{rxT}}=100 \mathrm{~g}_{\mathrm{RxT}} / \mathrm{A}_{\mathrm{eff}} \quad\left(\mathrm{W}^{-1} \mathrm{~km}^{-1}\right) .
$$

where, $\mathrm{g}_{\mathrm{RxT}}$ (in $10^{-13} \mathrm{~m} / \mathrm{W}$ ) and $\mathrm{A}_{\text {eff }}$ (in $\mu \mathrm{m}^{2}$ )

Finally, the value of $g_{R x T}$ increases with $x_{1}$ but it decreases with $T$ as explained in [15]. Also, the value of $g_{r x T}$ decreases with core radius as explained in [15].

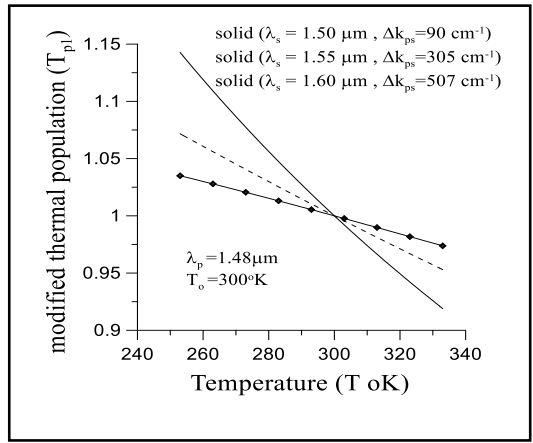

Fig.5 Modified thermal population $\mathrm{T}_{\mathrm{p} 1}$

\section{II.4 Raman amplifier}

From the propagation coupled equations [16] between the optical power of input signal $\left(\mathrm{P}_{\mathrm{s}}\right)$ and the optical power of pump $\left(\mathrm{P}_{\mathrm{p}}\right)$ and with assume that, the pump depletion $\left\{-\frac{\lambda_{s}}{\lambda_{\mathrm{p}}} \mathrm{g}_{\mathrm{rxT}} \mathrm{P}_{\mathrm{s}}(\mathrm{z}) \mathrm{P}_{\mathrm{p}}(\mathrm{z})\right\}[16]$ is very small, the signal power distribution, $\mathrm{P}_{\mathrm{s}}(\mathrm{z})$, of dual pumps is derived as;

$$
\mathrm{P}_{\mathrm{SD}}(\mathrm{z})=\mathrm{P}_{\mathrm{S} 0} \mathrm{e}^{-\alpha_{\mathrm{s}} \mathrm{z}} * \operatorname{Exp}\left\{\left[\frac{\mathrm{g}_{\mathrm{rxT}} \mathrm{P}_{\mathrm{p}}\left(1-\mathrm{e}^{-\alpha_{\mathrm{p} z}}\right)}{\alpha_{\mathrm{p}}}\right]\left[\mathrm{S}+(1-\mathrm{S}) \mathrm{e}^{-\alpha_{\mathrm{p}}(\mathrm{L}-\mathrm{z})}\right]\right\}
$$

Where, $P_{s 0}$ is the optical input signal at $\mathrm{z}=0, \alpha_{\mathrm{s}}\left(\mathrm{km}^{-1}\right)$ is the attenuation coefficient for optical signal at $\lambda_{\mathrm{s}}, \mathrm{P}_{\mathrm{p}}$ is the summation of input pumps power (forward pump, $\mathrm{P}_{\mathrm{pF}}$, at $\mathrm{z}=0$ (in z-direction) with wavelength, $\lambda_{\mathrm{p}}$, and backward pump, $\mathrm{P}_{\mathrm{pB}}$, at $\mathrm{z}=\mathrm{L}$ (in negative $\mathrm{z}$-direction), with the same wavelength, $\lambda_{\mathrm{p}}$,), $\alpha_{\mathrm{p}}\left(\mathrm{km}^{-1}\right)$ is the attenuation coefficient for optical pump at $\lambda_{\mathrm{p}}$, $\mathrm{g}_{\mathrm{rxT}}$ is the Raman coefficient $\left(\mathrm{W}^{-1} \mathrm{~km}^{-1}\right), \mathrm{S}(0 \leq \mathrm{S} \leq 1)$ is the ratio of pump power at $\mathrm{z}=0$ to the total pump power, therefore $\mathrm{P}_{\mathrm{pF}}=S \mathrm{P}_{\mathrm{p}}$ and $\mathrm{P}_{\mathrm{pB}}=(1-\mathrm{S}) \mathrm{P}_{\mathrm{p}}$ and $\mathrm{L}$ is the amplifier length.

From Eq.8.a, the final signal power at $\mathrm{z}=\mathrm{L}$;

$$
\mathrm{P}_{\mathrm{sD}}(\mathrm{L})=\mathrm{P}_{\mathrm{s} 0} \mathrm{e}^{-\alpha_{\mathrm{s}} \mathrm{L}} \operatorname{Exp}\left\{\mathrm{g}_{\mathrm{rxT}} \mathrm{P}_{\mathrm{p}} \mathrm{L}_{\mathrm{eff}}\right\}
$$


Also from Eq.8.a, the Raman amplifier gain, $\mathrm{G}_{\mathrm{D}}(\mathrm{z})$ is;

$$
\mathrm{G}_{\mathrm{D}}(\mathrm{z})=P_{S D}(\mathrm{z}) / P_{S D}(0)=\mathrm{e}^{-\alpha_{\mathrm{s}} \mathrm{z}} * \operatorname{Exp}\left\{\left[\frac{g_{\mathrm{rxT}} \mathrm{P}_{\mathrm{p}}\left(1-\mathrm{e}^{-\alpha_{\mathrm{p}} \mathrm{z}}\right)}{\alpha_{\mathrm{p}}}\right]\left[\mathrm{S}+(1-\mathrm{S}) \mathrm{e}^{-\alpha_{\mathrm{p}}(\mathrm{L}-\mathrm{z})}\right]\right\} .
$$

The final gain $\mathrm{G}_{\mathrm{D}}$ at $\mathrm{z}=\mathrm{L}$

$$
G_{D}=e^{-\alpha_{s} L} \quad \operatorname{Exp}\left\{g_{r x T} P_{p} L_{e f f}\right\}
$$

Special case 1: with $S=1$ (i.e. Forward pump only), from Eq.8.a, $P_{s D}(z)$ becomes $P_{s F}(z)$ as;

$$
\mathrm{P}_{\mathrm{sF}}(\mathrm{z})=\mathrm{P}_{\mathrm{s} 0} \mathrm{e}^{-\alpha_{\mathrm{s}} \mathrm{z}} * \operatorname{Exp}\left\{\left[\frac{\mathrm{g}_{\mathrm{rxT}} \mathrm{P}_{\mathrm{p}}\left(1-\mathrm{e}^{-\alpha_{\mathrm{p} z}}\right)}{\alpha_{\mathrm{p}}}\right]\right\} \quad \text { as indicated in [17] }
$$

Special case 2: with $S=0$ (i.e. Backward pump only), from Eq.8.a, $P_{\mathrm{sD}}(\mathrm{z})$ becomes $\mathrm{P}_{\mathrm{sB}}(\mathrm{z})$ as;

$$
\mathrm{P}_{\mathrm{SB}}(\mathrm{z})=\mathrm{P}_{\mathrm{s} 0} \mathrm{e}^{-\alpha_{\mathrm{s}} \mathrm{z}} \operatorname{Exp}\left\{\left[\frac{\mathrm{g}_{\mathrm{rxT}} \mathrm{P}_{\mathrm{p}}\left(1-\mathrm{e}^{-\alpha_{\mathrm{p} z}}\right)}{\alpha_{\mathrm{p}}}\right]\left[\mathrm{e}^{-\alpha_{\mathrm{p}}(\mathrm{L}-\mathrm{z})}\right]\right\} \quad \text { as indicated in [17]... }
$$

Then the final gain (gain at $\mathrm{z}=\mathrm{L}$ ) of forward pump $\left(\mathrm{G}_{\mathrm{F}}\right)$, backward pump $\left(\mathrm{G}_{\mathrm{B}}\right)$ and dual pumps $\left(\mathrm{G}_{\mathrm{D}}\right)$ are equally as ;

$$
\mathrm{G}=\mathrm{G}_{\mathrm{F}}(\mathrm{db})=\mathrm{G}_{\mathrm{B}}(\mathrm{db})=\mathrm{G}_{\mathrm{D}}(\mathrm{db})=-4.343 \alpha_{\mathrm{s}} \mathrm{L}+4.343 \mathrm{~g}_{\mathrm{rxT}} \mathrm{L}_{\mathrm{eff}} \mathrm{P}_{\mathrm{p}}
$$

As explained in [18]. So, gain $(G)$ decreases with fiber core radius (a) where $g_{\text {rxT }}$ decreases with a (because, $A_{\text {eff }}$ increases with a).

\section{Maximized and minimized values of $P_{s}(z)$}

* For dual pumps, by putting $\mathrm{dP}_{\mathrm{sD}}(\mathrm{z}) / \mathrm{dz}=0$ of Eq.8.a, there are maximized value of $\mathrm{P}_{\mathrm{sD}}\left(\mathrm{P}_{\mathrm{sDmax}}\right.$ occurs at $\left.\mathrm{Z}_{\mathrm{Dmax}}\right)$ and minimized value of $\mathrm{P}_{\mathrm{SD}}\left(\mathrm{P}_{\mathrm{sDmin}}\right.$ occurs at $\left.\mathrm{Z}_{\mathrm{Dmin}}\right)$ where,

$$
\mathrm{z}_{\mathrm{Dmax}}=-\frac{1}{\alpha_{\mathrm{p}}} \ln \left(\mathrm{y}_{1}\right) \quad \text { and } \quad \mathrm{z}_{\mathrm{Dmin}}=-\frac{1}{\alpha_{\mathrm{p}}} \ln \left(\mathrm{y}_{2}\right) .
$$

Where, $\mathrm{y}_{1}\left(0<\mathrm{y}_{1}<1\right)$ and $\mathrm{y}_{2}\left(0<\mathrm{y}_{2}<1\right)$ are the two solutions of the following equation;

$$
\mathrm{s} \mathrm{y}^{2}-\frac{\alpha_{\mathrm{s}}}{\mathrm{P}_{\mathrm{p}} \mathrm{g}_{\mathrm{rxT}}} \mathrm{y}+(1-\mathrm{S}) \mathrm{e}^{-\alpha_{\mathrm{p}} \mathrm{L}}=0 \quad\left\{\text { where, } \mathrm{y}=\exp \left(-\alpha_{\mathrm{p}} \mathrm{z}\right)\right\}
$$

So,

$$
y_{1,2}=\frac{\alpha_{s}}{2 S P_{p} g_{r x T}} \pm y_{y}^{0.5} \quad \text { where } y_{y}=\left(\frac{\alpha_{s}}{2 S P_{p} g_{r x T}}\right)^{2}-\left(s^{-1}-1\right) e^{-\alpha_{p} L} \text {. }
$$

i- With $\mathbf{y}_{\mathbf{y}}>\mathbf{0}$, in this case;

$$
\begin{aligned}
& \mathrm{P}_{\mathrm{p}}^{2}<\frac{1}{\left(\mathrm{~S}-\mathrm{S}^{2}\right)} \frac{\alpha_{\mathrm{s}}^{2}}{4 \mathrm{~g}_{\mathrm{rxt}}^{2}} \mathrm{e}^{\alpha_{\mathrm{p}} \mathrm{L}} \\
& \mathrm{zZ}=\mathrm{z}_{\text {Dmax }}+\mathrm{z}_{\text {Dmin }}=\mathrm{L}-\frac{1}{\alpha_{\mathrm{p}}} \ln \left(\frac{1-\mathrm{S}}{\mathrm{s}}\right)
\end{aligned}
$$

So, $\mathrm{zz}<\mathrm{L}$ (with $0<\mathrm{S}<0.5$ ), $\mathrm{zZ}=\mathrm{L}$ (with $\mathrm{S}=0.5$ ) and $\mathrm{zz}>\mathrm{L}$ (with $0.5<\mathrm{S}<1.0$ )

ii-With $\mathbf{y}_{\mathbf{y}}=\mathbf{0}$, in this case $\left(\mathrm{y}_{1}=\mathrm{y}_{2}=\frac{\alpha_{\mathrm{s}}}{2 \mathrm{~S} \mathrm{P}_{\mathrm{p}} \mathrm{grxT}_{\mathrm{rxT}}}\right)$,

$$
\mathrm{P}_{\mathrm{p}}^{2}=\frac{1}{\left(\mathrm{~S}-\mathrm{S}^{2}\right)} \frac{\alpha_{\mathrm{s}}^{2}}{4 \mathrm{~g}_{\mathrm{rxt}}^{2}} \mathrm{e}^{\alpha_{\mathrm{p}} \mathrm{L}}
$$

Therefore,

$$
\mathrm{z}_{\mathrm{Dmax}}=\mathrm{z}_{\mathrm{Dmin}}=\frac{-1}{\alpha_{\mathrm{p}}} \ln \left(\frac{\alpha_{\mathrm{s}}}{2 \mathrm{SP} \mathrm{g}_{\mathrm{rxT}}}\right) \quad, \mathrm{z}_{\mathrm{Dmin}}=\mathrm{L}-\mathrm{z}_{\mathrm{Dmax}}
$$

iii-With $\mathbf{y}_{\mathbf{y}}<\mathbf{0}$, in this case, the two solutions $\left(\mathrm{y}_{1}\right.$ and $\left.\mathrm{y}_{2}\right)$ become complex and the gain distribution hasn't peak with;

$$
\mathrm{P}_{\mathrm{p}}^{2}>\frac{1}{\left(\mathrm{~S}-\mathrm{S}^{2}\right)} \frac{\alpha_{\mathrm{s}}^{2}}{4 \mathrm{~g}_{\mathrm{rxt}}^{2}} \mathrm{e}^{\alpha_{\mathrm{p}} \mathrm{L}}
$$

Note, the value of $\left(S-S^{2}\right)$ always greater than zero and it has maximum value at $S=0.5$. Therefore, the required $P_{p}$ to give maximized and minimized values of gain, the value of $P_{p}$ becomes lowest at $S=0.5$

*For forward pump only, the position of maximized value is derived from Eq.13.a as;

$$
\mathrm{z}_{\mathrm{Fmax}}=\frac{1}{\alpha_{\mathrm{p}}} \ln \left(\mathrm{P}_{\mathrm{pF} 0} \mathrm{~g}_{\mathrm{rxT}} / \alpha_{\mathrm{s}}\right) \text {. }
$$

This expression can be also defined from Eq.14.a by putting $S=1$. Although, the value of $\mathrm{Z}_{\mathrm{Fmax}}$ increases with both $\mathrm{P}_{\mathrm{pF} 0}$ and $\mathrm{g}_{\mathrm{rxT}}$ but it decreases with both $\alpha_{\mathrm{p}}$ and $\alpha_{\mathrm{s}}$ (i.e., $\mathrm{z}_{\mathrm{Fmax}}$ decreases with $\mathrm{x}_{1}$ and $\mathrm{T}$ ). The value of $\mathrm{z}_{\mathrm{Fmax}}$ is named as the optimum Raman length, Loptimum [16].

* For backward pump only, the position of minimized value is derived from Eq.14.a as;

$$
\mathrm{z}_{\mathrm{Bmin}}=\mathrm{L}-\frac{1}{\alpha_{\mathrm{p}}} \ln \left(\mathrm{P}_{\mathrm{pBL}} \mathrm{g}_{\mathrm{rxT}} / \alpha_{\mathrm{s}}\right)=\mathrm{L}-\mathrm{z}_{\mathrm{Fmax}}
$$

This expression can be also defined from Eq.14. a by putting $S=0$. 


\section{II.5 Optimum pump wavelength $\left(\lambda_{\mathrm{p}}\right)$, Threshold pump power $\left(\mathbf{P}_{\text {pthr }}\right)$ and Gain saturation $\left(\mathbf{G}_{\mathrm{s}}\right)$}

* The optimum pump wavelength $\left(\lambda_{\mathrm{p}}\right)$ is selected to give; (i) higher bandwidth (around 100nm, with $\lambda_{\mathrm{s}}$ usually ranged between 1.50 to $1.60 \mu \mathrm{m}$ ), (ii) higher value of $\mathrm{g}_{\mathrm{R} 0}$ (which occurs with $\Delta \mathrm{k}_{\mathrm{ps}}=90$ to $580 \mathrm{~cm}^{-1} \mathrm{as}$ shown in Fig.3. So, for $\lambda_{\mathrm{s}}=1.50$ to $1.60 \mu \mathrm{m}$ and from Eq.4.a, the corresponding value of $\lambda_{\mathrm{p}}=1.48 \mu \mathrm{m}$ ), (iii) lower $A_{p}$ (i.e., lower value of $\lambda_{p}$ to give more $g_{r x T}$ ) and (iv) lower $\alpha_{p}$ (i.e., higher value of $\lambda_{p}$ to give more value of $L_{e f f}$ ). Although, the optimum value of $\lambda_{p}$ ranges between 1.4 to $1.5 \mu \mathrm{m}$ (this range of $\lambda_{\mathrm{p}}$ is used to avoid noise and losses). For wideband Raman amplifier, each pump wavelength is best for some signal wavelengths and vice versa for the other signal wavelengths, as indicated in Table 1.

Table1: Effect of pump wavelength $\left(\lambda_{\mathrm{p}}\right)$ on the Raman amplifier gain $(\mathrm{G})$ at several signal wavelengths $\left(\lambda_{\mathrm{s}}\right)$. Amplifier data is stated in section 3 below

\begin{tabular}{|c|c|c|c|c|c|}
\hline & & $\lambda_{\mathrm{p}}=1.46 \mu \mathrm{m}$ & $\lambda_{\mathrm{p}}=1.47 \mu \mathrm{m}$ & $\lambda_{\mathrm{p}}=1.48 \mu \mathrm{m}$ & $\lambda_{\mathrm{p}}=1.49 \mu \mathrm{m}$ \\
\hline \multirow{3}{*}{ Gain $(\mathrm{db})$} & $\lambda_{\mathrm{s}}=1.50 \mu \mathrm{m}$ & 1.63 & -2.30 & -4.79 & 40.93 \\
\cline { 2 - 6 } & $\lambda_{\mathrm{s}}=1.55 \mu \mathrm{m}$ & 46.27 & 34.32 & 20.23 & 8.30 \\
\cline { 2 - 6 } & $\lambda_{\mathrm{s}}=1.60 \mu \mathrm{m}$ & -9.42 & 9.32 & 35.90 & 14.93 \\
\hline
\end{tabular}

* Threshold pump power $\left(\mathbf{P}_{\text {pthr }}\right)$ is defined as the incident power at which half of the pump power is transferred to the Stokes field at the output end of a fiber of length L [19]. It is defined as [19-22];

$$
\begin{array}{ll}
\mathrm{P}_{\mathrm{pF} \text { thr }}=16 /\left(\mathrm{g}_{\mathrm{rxt}} \mathrm{L}_{\mathrm{eff}}\right) & \text { (Forward pump }) \ldots \\
\mathrm{P}_{\mathrm{pB} \text { thr }}=20 /\left(\mathrm{g}_{\text {rxt }} \mathrm{L}_{\mathrm{eff}}\right) & \text { (Backward pump }) .
\end{array}
$$

Therefore, as $\mathrm{T}$ increases, the value of $\mathrm{P}_{\text {pthr }}$ increases (where both $\mathrm{L}_{\text {eff }}$ and $\mathrm{g}_{\mathrm{rxT}}$ are lowered with higher $\mathrm{T}$ ) and vice versa for the Germania ratio (because as $\mathrm{x}_{1}$ increases, $\mathrm{g}_{\mathrm{rxT}}$ increases but $\mathrm{L}_{\text {eff }}$ decreases, while the product $\mathrm{g}_{\mathrm{rxT}} \mathrm{L}_{\mathrm{eff}}$ increases with $\left.\mathrm{x}_{1}\right)$. Pump power must be greater than the threshold pump power $\left(\mathrm{P}_{\mathrm{p}}>\mathrm{Ppthr}\right)$ [23]

* Gain saturation (Gs): The amplification factor $(\mathrm{G} d b)$ increases linearly with $\mathrm{P}_{\mathrm{pF} 0}$ (Eq.13.a), but experimentally the relation between gain $(\mathrm{db})$ and the pump power deviate from linearity after the value of gain saturation $\mathrm{G}_{\mathrm{s}}$ (where $\mathrm{G}_{\mathrm{s}}$ occurring because of pump depletion) [6]. The gain saturation is defined as [6];

$$
\mathrm{G}_{\mathrm{s}}=\frac{1+\mathrm{r}_{\mathrm{o}}}{\mathrm{r}_{\mathrm{o}}+\mathrm{G}_{\mathrm{a}}^{-\left(1+\mathrm{r}_{0}\right)}}
$$

Where, $\mathrm{G}_{\mathrm{a}}=\exp \left(\mathrm{g}_{\mathrm{rxt}} \mathrm{P}_{\mathrm{pF} 0} \mathrm{~L}_{\mathrm{eff}}\right) \quad$ and $\quad \mathrm{r}_{\mathrm{o}}=\left(\lambda_{\mathrm{s}} \mathrm{P}_{\mathrm{s} 0}\right) /\left(\lambda_{\mathrm{p}} \mathrm{P}_{\mathrm{pF} 0}\right)$

Although, as the amplifier length (L) increases (i.e., $\mathrm{L}_{\mathrm{eff}}$ increases), $\mathrm{G}_{\mathrm{s}}$ increases. But, as pump power $\left(\mathrm{P}_{\mathrm{p} 0}\right)$ increases, $\mathrm{G}_{\mathrm{s}}$ decreases as shown in Fig.6

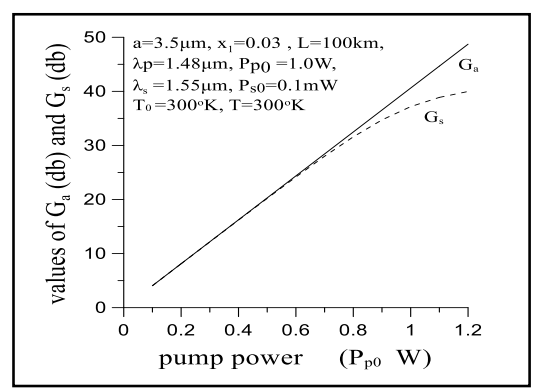

Fig.6 Effect of $\mathrm{P}_{\mathrm{p} 0}$ on the saturation gain $\left(\mathrm{G}_{\mathrm{s}}\right)$

\section{Simulation Results and Discussions}

In this study the main data is $\mathrm{a}=3.5 \mu \mathrm{m}, \mathrm{x}_{1}=0.03$ to $0.05, \mathrm{~L}=100 \mathrm{~km}, \lambda_{\mathrm{p}}=1.48 \mu \mathrm{m}, \mathrm{P}_{\mathrm{p}}=1.0 \mathrm{~W}, \mathrm{~T}_{0}=300^{\circ} \mathrm{K}, \mathrm{T}=253$ to $333^{\circ} \mathrm{K}, \mathrm{P}_{\mathrm{s} 0}=0.1 \mathrm{~mW}$, and $\lambda_{\mathrm{s}}=1.50 \mu \mathrm{m}$ to $1.60 \mu \mathrm{m}$ (i.e., $\Delta \mathrm{k}_{\mathrm{ps}}$ increases from $90 \mathrm{~cm}^{-1}$ to $507 \mathrm{~cm}^{-1}$ ). This data is used with both forward, backward and dual pumps (with $\mathrm{S}=0.5$ ).

Simulation example 1: Effect of $\mathrm{x}_{1}, \mathrm{~T}$ and $\lambda_{\mathrm{s}}$ on the performance of amplifier. The results are shown in Fig.7 and Tables 2.a and 2.b which show that;

- Gain distribution of the dual pumps $\left(G_{D}\right)$ is the best (especially at $S=0.5$ ) than that gain distributions of forward $\left(\mathrm{G}_{\mathrm{F}}\right)$ and backward $\left(\mathrm{G}_{\mathrm{B}}\right)$ pumps.

- The summation of $\mathrm{z}_{\mathrm{F} \max }+\mathrm{z}_{\mathrm{Bmin}}=\mathrm{L}$ (as explained) 
-The difference $\left(\Delta \mathrm{G}_{\mathrm{as}}=\mathrm{G}_{\mathrm{a}}-\mathrm{G}_{\mathrm{s}}\right)$ between Raman amplifier gain $\left(\mathrm{G}_{\mathrm{a}}\right)$ and saturation gain $\left(\mathrm{G}_{\mathrm{s}}\right)$ very little at $\lambda_{\mathrm{s}}=1.5 \mu \mathrm{m}$ but it becomes large at $\lambda_{\mathrm{s}}=1.6 \mu \mathrm{m}$. Also, $\Delta \mathrm{G}_{\mathrm{as}}$ decreases with temperature $(\mathrm{T})$ but increases with Germania ratio $\left(\mathrm{x}_{1}\right)$.

- With $\mathrm{x}_{1}=0.03$ and $\mathrm{x}_{1}=0.05$, there aren't peaks $\left(\mathrm{y}_{\mathrm{y}}<0\right)$ at $\lambda_{\mathrm{s}}=1.55 \mu \mathrm{m}(\mathrm{T}=253 \mathrm{~K}), \lambda_{\mathrm{s}}=1.60 \mu \mathrm{m},(\mathrm{T}=253 \mathrm{~K})$ and $\lambda_{\mathrm{s}}=160 \mu \mathrm{m}(\mathrm{T}=300 \mathrm{~K})$.

- Finally; the amplifier gain $\left(\mathrm{G}=-4.343 \alpha_{\mathrm{s}} \mathrm{L}+4.343 \mathrm{~g}_{\mathrm{rx} T} \mathrm{~L}_{\mathrm{eff}} \mathrm{P}_{\mathrm{p}}\right)$ decreases with $\mathrm{T}$ but it increases with $\mathrm{x}_{1}$ and $\lambda_{\mathrm{s}}$. Where, $\alpha_{\mathrm{s}}$ decreases with $\lambda_{\mathrm{s}}$ until $\lambda_{\mathrm{s}}<\lambda_{\min }$ and vice versa for $\lambda_{\mathrm{s}}>\lambda_{\min }$. Table 2.c indicates that, the conclusion of effect of $\mathrm{x}_{1}, \mathrm{~T}$ and $\lambda_{\mathrm{s}}$ on all parameters of Raman amplifier. Also Fig.8 shows the effect of $\mathrm{x}_{1}$ and $\mathrm{T}$ on the amplifier gain.

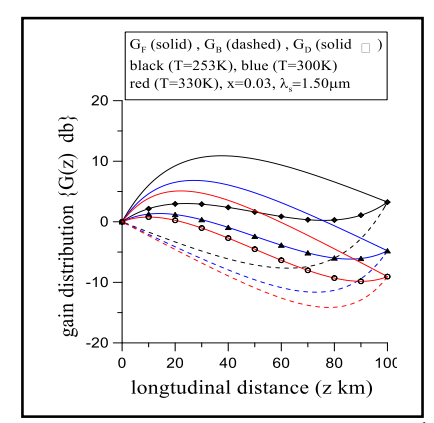

a) $\lambda_{\mathrm{s}}=1.50 \mu \mathrm{m}\left(\Delta \mathrm{k}_{\mathrm{ps}}=90 \mathrm{~cm}^{-1}\right)$

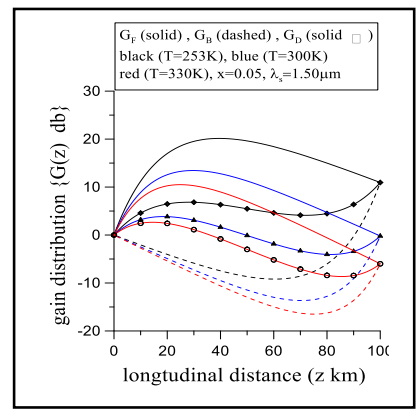

d) $\lambda_{\mathrm{s}}=1.50 \mu \mathrm{m}\left(\Delta \mathrm{k}_{\mathrm{ps}}=90 \mathrm{~cm}^{-1}\right)$

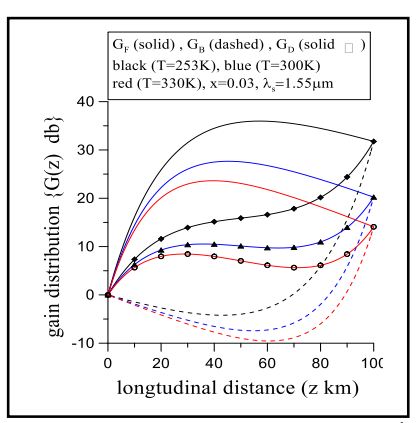

b) $\lambda_{\mathrm{s}}=1.55 \mu \mathrm{m}\left(\Delta \mathrm{k}_{\mathrm{ps}}=305 \mathrm{~cm}^{-1}\right)$

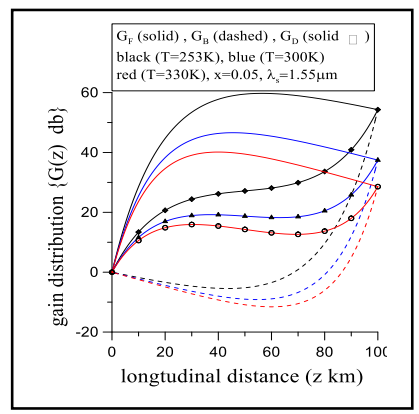

e) $\lambda_{\mathrm{s}}=1.55 \mu \mathrm{m}\left(\Delta \mathrm{k}_{\mathrm{ps}}=305 \mathrm{~cm}^{-1}\right)$

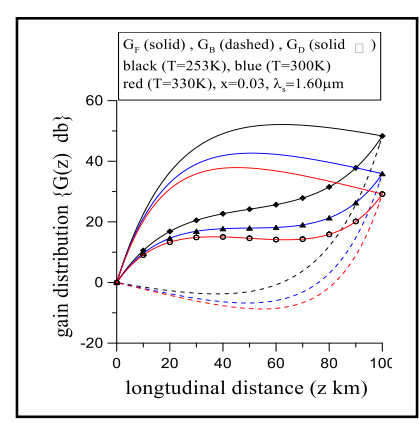

c) $\lambda_{\mathrm{s}}=1.60 \mu \mathrm{m}\left(\Delta \mathrm{k}_{\mathrm{ps}}=507 \mathrm{~cm}^{-1}\right)$

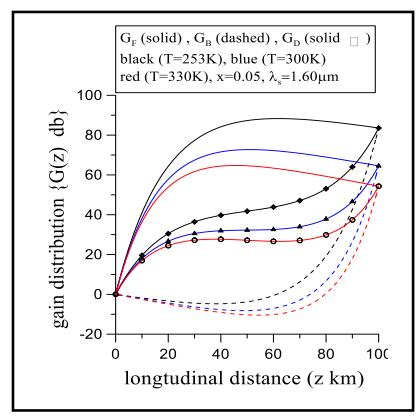

f) $\lambda_{\mathrm{s}}=1.60 \mu \mathrm{m}\left(\Delta \mathrm{k}_{\mathrm{ps}}=507 \mathrm{~cm}^{-1}\right)$

Fig.7 Gain distribution through the amplifier length, for forward pump $\left(\mathrm{G}_{\mathrm{F}}\right)$, backward pump $\left(\mathrm{G}_{\mathrm{B}}\right)$ and dual pumps $\left(\mathrm{G}_{\mathrm{D}}\right)$ with $\lambda_{\mathrm{p}}=1.48 \mu \mathrm{m}, \mathrm{P}_{\mathrm{p}}=1 \mathrm{~W}, \mathrm{~T}_{0}=300 \mathrm{~K}, \mathrm{~L}=100 \mathrm{~km}$,

Upper figures $\mathrm{x}_{1}=0.03$ and lower figures $\mathrm{x}_{1}=0.05$ 
Table 2.a: Design example 1: Effect of $\mathrm{T}$ and $\lambda_{\mathrm{s}}$ on

$\alpha_{\mathrm{s} 1}$, Att $, \alpha_{\mathrm{p} 1}, \mathrm{~L}_{\mathrm{eff}}, \mathrm{g}_{\mathrm{rxT}}, \mathrm{G}, \mathrm{Z}_{\mathrm{Fmax}}, \mathrm{G}_{\mathrm{Fmax}}, \mathrm{Z}_{\mathrm{Bmin}}, \mathrm{G}_{\mathrm{Bmin}}, \mathrm{Z}_{\mathrm{Dmax}}, \mathrm{G}_{\mathrm{Dmax}}, \mathrm{Z}_{\mathrm{Dmin}}, \mathrm{G}_{\mathrm{Dmin}}, \mathrm{P}_{\mathrm{thF}}, \mathrm{P}_{\mathrm{thB}}, \mathrm{P}_{\mathrm{pmaxD}}$.

With $\mathrm{x} 1=0.03$ and $\mathrm{Ps} 0=0.1 \mathrm{~mW}$

\begin{tabular}{|c|c|c|c|c|c|c|c|c|c|c|}
\hline \multicolumn{2}{|c|}{$\lambda_{s} \mu \mathrm{m}$} & \multicolumn{3}{|c|}{$\lambda_{\mathrm{s}}=1.50 \mu \mathrm{m}\left(\Delta \mathrm{k}_{\mathrm{ps}}=90\right)$} & \multicolumn{3}{|c|}{$\lambda_{\mathrm{s}}=1.55 \mu \mathrm{m}\left(\Delta \mathrm{k}_{\mathrm{ps}}=305\right)$} & \multicolumn{3}{|c|}{$\lambda_{\mathrm{s}}=1.60 \mu \mathrm{m}\left(\Delta \mathrm{k}_{\mathrm{ps}}=507\right)$} \\
\hline $\mathrm{T}$ & ${ }^{\circ} \mathrm{K}$ & 253 & 300 & 333 & 253 & 300 & 333 & 253 & 300 & 333 \\
\hline$\alpha_{s 1}$ & $\mathrm{db} / \mathrm{km}$ & 0.1853 & 0.2153 & 0.2345 & 0.1775 & 0.2038 & 0.2207 & 0.1934 & 0.2165 & 0.2315 \\
\hline $\mathrm{A}_{\mathrm{tt}}$ & $\mathrm{db}$ & -18.53 & -21.53 & -23.45 & -17.75 & -20.38 & -22.07 & -19.34 & -21.65 & -23.15 \\
\hline$\alpha_{\mathrm{p} 1}$ & $\mathrm{db} / \mathrm{km}$ & 0.1922 & 0.2238 & 0.2441 & 0.1922 & 0.2238 & 0.2441 & 0.1922 & 0.2238 & 0.2441 \\
\hline $\mathrm{L}_{\mathrm{eff}}$ & $\mathrm{km}$ & 22.32 & 19.29 & 17.73 & 22.32 & 19.30 & 17.73 & 22.32 & 19.29 & 17.73 \\
\hline $\mathrm{g}_{\mathrm{rxT}}$ & 1/W. km & 0.2247 & 0.1997 & 0.1870 & 0.5107 & 0.4846 & 0.4696 & 0.6982 & 0.6869 & 0.6795 \\
\hline G & $\mathrm{db}$ & 3.2455 & -4.79 & -9.05 & 31.76 & 20.24 & 14.09 & 48.35 & 35.90 & 29.17 \\
\hline $\mathrm{G}_{\mathrm{a}}$ & $\mathrm{db}$ & 21.78 & 16.73 & 14.4 & 49.5 & 40.61 & 36.16 & 67.68 & 57.55 & 52.32 \\
\hline $\mathrm{G}_{\mathrm{s}}$ & $\mathrm{db}$ & 21.19 & 16.55 & 14.29 & 29.84 & 37.17 & 28.91 & 29.67 & 29.66 & 29.65 \\
\hline ZFmax & $\mathrm{km}$ & 37.52 & 27.04 & 22.10 & 57.06 & 45.32 & 39.57 & 62.19 & 50.90 & 45.29 \\
\hline$G_{\text {Fmax }}$ & $\mathrm{db}$ & 10.90 & 6.83 & 5.10 & 35.97 & 27.66 & 23.63 & 52.11 & 42.67 & 37.90 \\
\hline$Z_{\text {Bmin }}$ & $\mathrm{km}$ & 62.48 & 72.96 & 77.90 & 42.94 & 54.69 & 60.43 & 37.81 & 49.10 & 54.71 \\
\hline $\mathrm{G}_{\text {Bmin }}$ & $\mathrm{db}$ & -11.58 & -15.70 & -18.27 & -7.62 & -11.14 & -13.34 & -7.31 & -10.63 & -12.66 \\
\hline ZDmax & $\mathrm{km}$ & 24.02 & 14.06 & 9.97 & No * & 35.96 & 28.80 & No* & No* & 36.48 \\
\hline $\mathrm{G}_{\operatorname{Dmax}}$ & $\mathrm{db}$ & 3.01 & 1.36 & 0.78 & $\mathrm{No}^{*}$ & 10.53 & 8.4584 & No* & No* & 15.07 \\
\hline$Z_{D \min }$ & $\mathrm{km}$ & 75.98 & 85.94 & 90.03 & $\mathrm{No}^{*}$ & 64.04 & 71.20 & $\mathrm{No}^{*}$ & $\mathrm{No}^{*}$ & 63.52 \\
\hline GDmin & $\mathrm{db}$ & 0.2323 & -6.156 & -9.83 & No* & 9.70 & 5.63 & No* & No* & 14.09 \\
\hline $\mathrm{P}_{\mathrm{thF}}$ & $\mathrm{W}$ & 3.1906 & 4.1528 & 4.8256 & 1.40 & 1.71 & 1.92 & 1.0266 & 1.2073 & 1.3283 \\
\hline $\mathrm{P}_{\mathrm{thB}}$ & $\mathrm{W}$ & 3.99 & 5.19 & 6.03 & 1.75 & 2.14 & 2.40 & 1.2833 & 1.5091 & 1.6604 \\
\hline $\mathrm{P}_{\mathrm{pDmax}}$ & $\mathrm{W}$ & 3.47 & 6.53 & 9.59 & 1.46 & 2.55 & 3.60 & 1.1662 & 1.9092 & 2.6061 \\
\hline
\end{tabular}

* Note; No means there isn't peaks $\left(\mathrm{y}_{\mathrm{y}}<0\right)$

Table 2.b: design example 2: Effect of $\mathrm{T}$ and $\lambda_{\mathrm{s}}$ on

$\alpha_{\mathrm{s} 1}$, Att $, \alpha_{\mathrm{p} 1} \mathrm{~L}_{\mathrm{eff}}, \mathrm{g}_{\mathrm{rxT}}, \mathrm{G}, \mathrm{Z}_{\mathrm{Fmax}}, \mathrm{G}_{\mathrm{Fmax}}, \mathrm{Z}_{\mathrm{Bmin}}, \mathrm{G}_{\mathrm{Bmin}}, \mathrm{Z}_{\mathrm{Dmax}}, \mathrm{G}_{\mathrm{Dmax}}, \mathrm{Z}_{\text {Dmin }}, \mathrm{G}_{\text {Dmin }}, \mathrm{P}_{\mathrm{thF}}, \mathrm{P}_{\mathrm{thB}}, \mathrm{P}_{\mathrm{pmaxD}}$

With $\mathrm{x} 1=0.05$ and $\mathrm{Ps} 0=0.1 \mathrm{~mW}$

\begin{tabular}{|c|c|c|c|c|c|c|c|c|c|c|}
\hline \multicolumn{2}{|c|}{$\lambda_{\mathrm{s}}$} & \multicolumn{3}{|c|}{$\lambda_{\mathrm{s}}=1.50 \mu \mathrm{m}\left(\Delta \mathrm{k}_{\mathrm{ps}}=90\right)$} & \multicolumn{3}{|c|}{$\lambda_{\mathrm{s}}=1.55 \mu \mathrm{m}\left(\Delta \mathrm{k}_{\mathrm{ps}}=305\right)$} & \multicolumn{3}{|c|}{$\lambda_{\mathrm{s}}=1.60 \mu \mathrm{m}\left(\Delta \mathrm{k}_{\mathrm{ps}}=507\right)$} \\
\hline $\mathrm{T}$ & ${ }^{\circ} \mathrm{K}$ & 253 & 300 & 333 & 253 & 300 & 333 & 253 & 300 & 333 \\
\hline$\alpha_{\mathrm{s} 1}$ & $\mathrm{db} / \mathrm{km}$ & 0.2182 & 0.2525 & 0.2747 & 0.2066 & 0.2368 & 0.2563 & 0.2193 & 0.2459 & 0.2632 \\
\hline $\mathrm{A}_{\mathrm{tt}}$ & $\mathrm{db}$ & -21.82 & -25.25 & -27.47 & -20.66 & -23.68 & -25.63 & -21.93 & -24.59 & -26.32 \\
\hline$\alpha_{\mathrm{p} 1}$ & $\mathrm{db} / \mathrm{km}$ & 0.2267 & 0.2630 & 0.2863 & 0.2267 & 0.2630 & 0.2863 & 0.2267 & 0.2630 & 0.2863 \\
\hline Leff & $\mathrm{km}$ & 19.05 & 16.48 & 15.15 & 19.053 & 16.48 & 15.15 & 926.9 & 16.48 & 15.15 \\
\hline $\mathrm{g}_{\mathrm{rxT}}$ & 1/W. km & 0.3961 & 0.3500 & 0.3264 & 0.9060 & 0.8542 & 0.8239 & 1.2751 & 1.2456 & 1.2257 \\
\hline $\mathrm{G}$ & $\mathrm{db}$ & 10.95 & -0.206 & -6.00 & 54.30 & 37.45 & 28.57 & 83.57 & 64.54 & 54.32 \\
\hline $\mathrm{Ga}$ & $\mathrm{db}$ & 32.77 & 25.05 & 21.48 & 74.96 & 61.14 & 54.21 & 105.49 & 89.19 & 80.65 \\
\hline Gs & $\mathrm{db}$ & 28.15 & 23.86 & 20.92 & 29.81 & 29.80 & 29.79 & 29.67 & 29.67 & 29.67 \\
\hline ZFmax & $\mathrm{Km}$ & 39.55 & 29.65 & 24.89 & 56.44 & 45.44 & 39.99 & 61.85 & 51.05 & 45.61 \\
\hline $\mathrm{G}_{\text {Fmax }}$ & $\mathrm{db}$ & 20.14 & 13.45 & 10.50 & 59.75 & 46.60 & 40.14 & 88.31 & 72.73 & 64.75 \\
\hline ZBmin & $\mathrm{km}$ & 60.45 & 70.35 & 75.11 & 43.56 & 54.56 & 60.01 & 38.15 & 48.95 & 54.39 \\
\hline $\mathrm{G}_{\mathrm{Bmin}}$ & $\mathrm{db}$ & -13.19 & -17.77 & -20.63 & -9.00 & -12.92 & -15.38 & -8.367 & -12.04 & -14.31 \\
\hline ZDmax & $\mathrm{km}$ & 28.13 & 18.56 & 14.52 & No * & 37.16 & 30.61 & $\mathrm{No}^{*}$ & No* & 37.90 \\
\hline$G_{\operatorname{Dmax}}$ & $\mathrm{db}$ & 6.84 & 3.85 & 2.66 & $\mathrm{No}^{*}$ & 19.22 & 15.93 & $\mathrm{No}^{*}$ & No* & 27.70 \\
\hline$Z_{D \min }$ & $\mathrm{km}$ & 71.87 & 81.44 & 85.48 & No* & 62.84 & 69.39 & No* & No* & 62.10 \\
\hline $\mathrm{G}_{\text {Dmin }}$ & $\mathrm{db}$ & 4.11 & -4.05 & -8.65 & No* & 18.23 & 12.64 & No* & No* & 26.62 \\
\hline $\mathrm{P}_{\mathrm{thF}}$ & $\mathrm{W}$ & 2.1204 & 2.7744 & 3.2361 & 0.93 & 1.14 & 1.2821 & 0.6587 & 0.7796 & 0.8618 \\
\hline $\mathrm{P}_{\mathrm{thB}}$ & W & 2.65 & 3.47 & 4.05 & 1.16 & 1.42 & 1.6027 & 0.8233 & 0.9745 & 1.0772 \\
\hline $\mathrm{P}_{\mathrm{pDmax}}$ & $\mathrm{W}$ & 3.45 & 6.86 & 10.47 & 1.43 & 2.64 & 3.8700 & 1.0775 & 1.8771 & 2.6709 \\
\hline
\end{tabular}

* Note; No means there isn't peaks $\left(\mathrm{y}_{\mathrm{y}}<0\right)$

Table 2.c Conclusion of effect of $\mathrm{x}_{1}, \mathrm{~T}$ and $\lambda_{\mathrm{s}}$

\begin{tabular}{|l|l|l|l|l|l|l|l|l|l|l|l|l|l|l|l|l|}
\hline & $\alpha_{\mathrm{s}}$ & $\alpha_{\mathrm{p}}$ & $\mathrm{L}_{\text {eff }}$ & $\mathrm{g}_{\mathrm{rxT}}$ & $\mathrm{Z}_{\mathrm{Fmax}}$ & $\mathrm{G}_{\mathrm{Fmax}}$ & $\mathrm{Z}_{\mathrm{Bmin}}$ & $\mathrm{G}_{\mathrm{Bmin}}$ & $\begin{array}{l}\mathrm{Z}_{\mathrm{D}} \\
\max \end{array}$ & $\begin{array}{l}\mathrm{G}_{\mathrm{Dm}} \\
\mathrm{ax}\end{array}$ & $\begin{array}{l}\mathrm{Z}_{\mathrm{Dmi}} \\
\mathrm{n}\end{array}$ & $\begin{array}{l}\mathrm{G}_{\mathrm{Dm}} \\
\text { in }\end{array}$ & $\mathrm{P}_{\text {thr }}$ & $\mathrm{P}_{\mathrm{Dm}}$ & $\mathrm{G}_{\mathrm{s}}$ & $\mathrm{G}_{\mathrm{ax}}$ \\
\hline $\mathrm{x} 1$ & $\mathrm{H}$ & $\mathrm{H}$ & $\mathrm{L}$ & $\mathrm{H}$ & $\mathrm{H}$ & $\mathrm{L}$ & $\mathrm{L}$ & $\mathrm{H}$ & $\mathrm{L}$ & $\mathrm{H}$ & $\mathrm{L}$ & $\mathrm{H}$ & $\mathrm{L}$ & & & $\mathrm{H}$ \\
\hline $\mathrm{T}$ & $\mathrm{H}$ & $\mathrm{H}$ & $\mathrm{L}$ & $\mathrm{L}$ & $\mathrm{L}$ & $\mathrm{L}$ & $\mathrm{H}$ & $\mathrm{H}$ & $\mathrm{L}$ & $\mathrm{L}$ & $\mathrm{H}$ & $\mathrm{H}$ & $\mathrm{H}$ & $\mathrm{T}$ & & $\mathrm{L}$ \\
\hline$\lambda_{\mathrm{s}}$ & $\mathrm{L}$ & - & - & $\mathrm{H}$ & $\mathrm{H}$ & $\mathrm{H}$ & $\mathrm{L}$ & $\mathrm{L}$ & $\mathrm{H}$ & $\mathrm{H}$ & $\mathrm{L}$ & $\mathrm{H}$ & $\mathrm{L}$ & $\mathrm{L}$ & & $\mathrm{H}$ \\
\hline
\end{tabular}




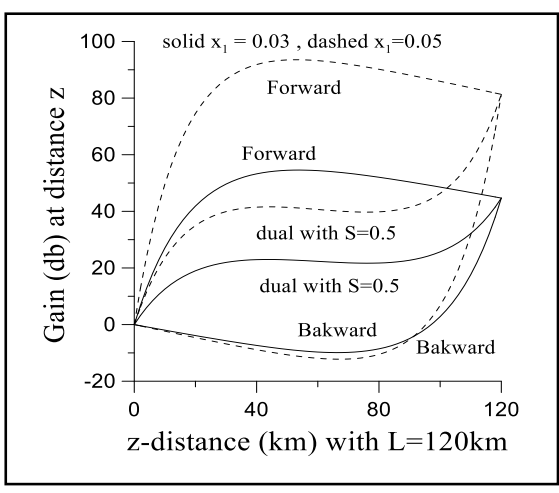

a) effect of $\mathrm{x}_{1}$ with $\mathrm{T}=300^{\circ} \mathrm{K}$

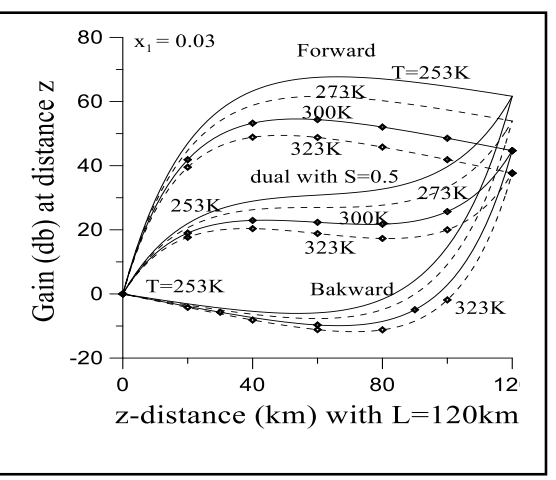

b) effect of $\mathrm{T}$ with $\mathrm{x}_{1}=0.03$

Fig.8 Effect of Germania ratio $\left(\mathrm{x}_{1}\right)$ and temperature $(\mathrm{T})$ on the performance of Raman amplifier $\lambda_{\mathrm{p}}=1.4553 \mu \mathrm{m}, \lambda_{\mathrm{s}}=1.55 \mu \mathrm{m}, \Delta \mathrm{k}_{\mathrm{ps}}=420 \mathrm{~cm}^{-1}, \mathrm{~T}_{\mathrm{o}}=300^{\circ} \mathrm{K}, \mathrm{a}=3.5 \mu \mathrm{m}, \mathrm{L}=120 \mathrm{~km}$

Simulation example 2; Effect of ratio $S$ (forward pump power / total input pump power) on the gain distribution:

With, $\lambda_{\mathrm{s}}=1.55 \mu \mathrm{m}, \mathrm{T}=300 \mathrm{~K}, \mathrm{x}_{1}=0.05$, the values of $\alpha_{\mathrm{s}}=0.2563 \mathrm{db} / \mathrm{km}, \alpha_{\mathrm{p}}=0.2861 \mathrm{db} / \mathrm{km}, \Delta \mathrm{k}_{\mathrm{ps}}=305 \mathrm{~cm}^{-1}$, $\mathrm{L}_{\mathrm{eff}}=15.15 \mathrm{~km}, \mathrm{~g}_{\mathrm{rxt}}=0.8239 \mathrm{~W}^{-1} \mathrm{~km}^{-1}$ and gain $\mathrm{G}=28.57 \mathrm{db}$. For dual pumps, the values of $\mathrm{Z}_{\mathrm{Dmax}}, \mathrm{G}_{\mathrm{Dmax}}$ and $\mathrm{Z}_{\mathrm{Dmin}} \mathrm{G}_{\mathrm{Dmin}}$ are increased with the parameter $\mathrm{S}$ as indicated in Table 3.

The best value of parameter at $S=0.5$ (dual pump) which makes the maximum and minimum values of the amplifier gain are little as shown in Fig.9. The summation of $Z_{D \max }+Z_{D \min }<\mathrm{L}$ (where $\mathrm{S}<0.5$ ) but $\mathrm{Z}_{\mathrm{Dmax}}+\mathrm{Z}_{\mathrm{Dmin}}>$ $\mathrm{L}$ (with $\mathrm{S}>0.5$ ) while $\mathrm{Z}_{\mathrm{Dmax}}+\mathrm{Z}_{\mathrm{Dmin}}=\mathrm{L}$ (with $\mathrm{S}=0.5$ ) as explained above and as indicated in Table 3.

Table 3: Effect of $S$ on the values of $Z_{\text {Dmax }}, G_{\text {Dmax }}, Z_{D \min }, G_{\text {Dmin }}, P_{\text {Fth }}, P_{B t h}$ and $P_{\text {Dmax }}$

\begin{tabular}{|l|c|c|c|c|c|c|}
\hline \multicolumn{2}{|c|}{ Kind of pump } & Backward & \multicolumn{3}{c|}{ Dual } & Forward \\
\hline \multicolumn{1}{|c|}{ parameter } & unit & $\mathrm{S}=0.00$ & $\mathrm{~S}=0.25$ & $\mathrm{~S}=0.50$ & $\mathrm{~S}=0.75$ & $\mathrm{~S}=1.00$ \\
\hline $\mathrm{Z}_{\text {Dmax }}$ & $\mathrm{km}$ & - & 19.78 & 30.61 & 36.45 & 39.99 \\
\hline $\mathrm{Z}_{\text {Dmin }}$ & $\mathrm{km}$ & 60.01 & 63.55 & 69.39 & 80.22 & - \\
\hline $\mathrm{Z}_{\text {Dmax }}+\mathrm{Z}_{\text {Dmax }}$ & $\mathrm{km}$ & - & 83.33 & 100 & 116.67 & - \\
\hline $\mathrm{G}_{\text {Dmax }}$ & $\mathrm{db}$ & - & 4.97 & 15.93 & 27.87 & 40.14 \\
\hline $\mathrm{G}_{\text {Dmin }}$ & $\mathrm{db}$ & -15.38 & 0.70 & 12.64 & 23.60 & - \\
\hline $\mathrm{P}_{\text {Dmax }}$ & $\mathrm{W}$ & - & 2.234 & 1.935 & 2.234 & - \\
\hline $\mathrm{P}_{\text {Fth }}$ & $\mathrm{W}$ & - & - & - & - & 1.282 \\
\hline $\mathrm{P}_{\text {Bth }}$ & $\mathrm{W}$ & 1.603 & - & - & - & - \\
\hline
\end{tabular}

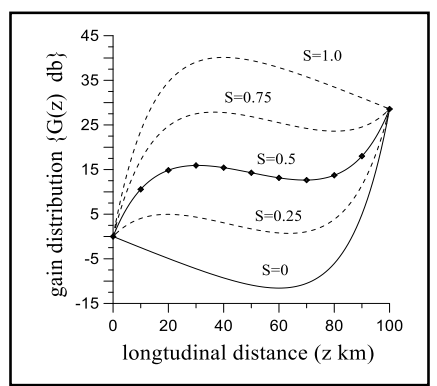

a) Gain with peaks $\left(\mathrm{y}_{\mathrm{y}}>0\right)$

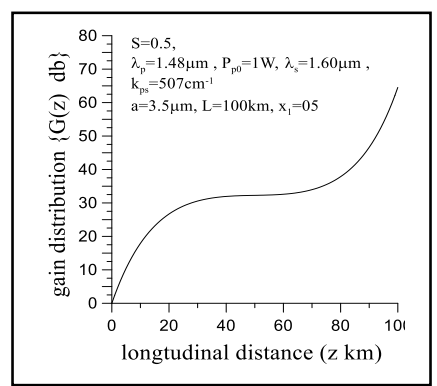

b) Gain without peaks $\left(\mathrm{y}_{\mathrm{y}} \leq 0\right)$

Fig.9 Gain of Raman amplifier with different values of $\mathrm{S}$

\section{Simulation example 3: Effect of signal wavelength $\left(\lambda_{s}\right)$ on Raman amplifier gain}

With $\mathrm{x}_{1}=0.05, \mathrm{a}=3.5 \mu \mathrm{m}, \lambda_{\mathrm{p}}=1.48 \mu \mathrm{m}, \mathrm{L}=100 \mathrm{~km}, \mathrm{~T}=300 \mathrm{Kand} \mathrm{P}_{\mathrm{p}}=0.5 \mathrm{~W}$;

- The values of $\alpha_{\mathrm{p}}=0.2630 \mathrm{db} / \mathrm{km}$ and $\mathrm{L}_{\mathrm{eff}}=16.48 \mathrm{~km}$

- The attenuation $\left(\alpha_{\mathrm{s}} \mathrm{L}\right)$ decreases from $25.25 \mathrm{db}\left(\right.$ at $\left.\lambda_{\mathrm{s}}=1.50 \mu \mathrm{m}\right)$ to $23.61 \mathrm{db}$ (at $\lambda_{\mathrm{s}}=1.563 \mu \mathrm{m}$ ) and increases again to $24.59 \mathrm{db}$ (at $\left.\lambda_{\mathrm{s}}=1.60 \mu \mathrm{m}\right)$, then the variation of attenuation around one $\mathrm{db}$ as shown in Fig. 9 . a.

- The effective cross section area $\left(\mathrm{A}_{\mathrm{eff}}\right)$ increases linearly from $53.7951 \mu \mathrm{m}^{2}$ (at $\left.\lambda_{\mathrm{s}}=1.50 \mu \mathrm{m}\right)$ to $56.8074 \mu \mathrm{m}^{2}($ at $\left.\lambda_{\mathrm{s}}=1.60 \mu \mathrm{m}\right)$. 
- The value of $\Delta \mathrm{k}_{\mathrm{ps}}$ increases from $90.09 \mathrm{~cm}^{-1}$ (at $\left.\lambda_{\mathrm{s}}=1.50 \mu \mathrm{m}\right)$ to $583.92 \mathrm{~cm}^{-1}$ (at $\lambda_{\mathrm{s}}=1.60 \mu \mathrm{m}$ ).

- The Raman gain coefficient $\left(\mathrm{g}_{\mathrm{rxT}}\right)$ increases from $0.3500 \mathrm{~W}^{-1} \mathrm{~km}^{-1}$ (at $\left.\lambda_{\mathrm{s}}=1.50 \mu \mathrm{m}\right)$ to $1.5756 \mathrm{~W}^{-1} \mathrm{~km}^{-1}$ (at $\left.\lambda_{\mathrm{s}}=1.5781 \mu \mathrm{m}\right)$ and it decreases to $0.3360 \mathrm{~W}^{-1} \mathrm{~km}^{-1}$ (at $\left.\lambda_{\mathrm{s}}=1.60 \mu \mathrm{m}\right)$ as shown in Fig.9. $\mathrm{b}$.

- From Eq.12.a,

$$
G=35.78 g_{r x T}-100 \alpha_{s 1} \mathrm{db} \quad \text { (where } \alpha_{\mathrm{s} 1} \text { in } \mathrm{db} / \mathrm{km} \text { ). }
$$

So, the profile of final Raman gain $(\mathrm{Gdb})$ approximately similar with the profile of Raman gain coefficient $\left(\mathrm{g}_{\mathrm{rxT}}\right.$ $\left.\mathrm{W}^{-1} \mathrm{~km}^{-1}\right)$ as shown in Figs.9.b and 9.c

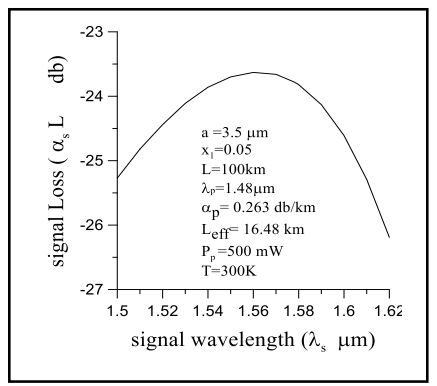

a) signal loss $\left(\alpha_{s} L\right)$

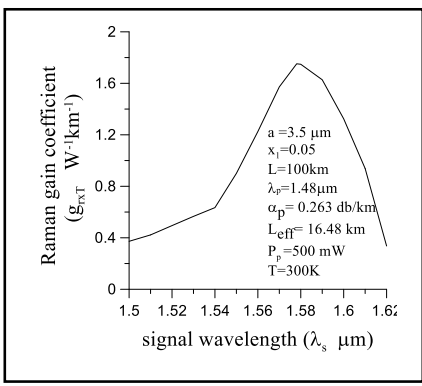

b) Raman gain coefficient $\left(\mathrm{g}_{\mathrm{rxT}}\right)$

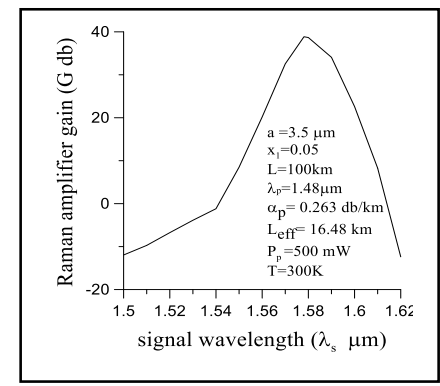

c) Raman gain $(\mathrm{G})$

Fig.10 The output gain as a function of signal wavelength $\left(\lambda_{\mathrm{s}}\right)$.

With $\mathrm{x}_{1}=0.05, \mathrm{a}=3.5 \mu \mathrm{m}, \lambda_{\mathrm{p}}=1.48 \mu \mathrm{m}, \mathrm{T}=300 \mathrm{~K}$ andP $\mathrm{p}=0.5 \mathrm{~W}$

\section{Simulation example 4: Effect of pump wavelength $\left(\lambda_{p}\right)$ on Raman amplifier gain}

The gain becomes peaks at $\lambda_{\mathrm{p}}=1.4553 \mu \mathrm{m}$ with $\lambda_{\mathrm{s}}=1.55 \mu \mathrm{m}$ as indicated in Table 4

Table 4: Effect of pump wavelength $\left(\lambda_{\mathrm{p}}\right)$ on the performance of Raman amplifier With $\lambda_{\mathrm{s}}=1.55 \mu \mathrm{m}, \mathrm{x}_{1}=0.03, \mathrm{~T}=300^{\circ} \mathrm{K}, \mathrm{T}_{\mathrm{o}}=300^{\circ} \mathrm{K}, \mathrm{a}=3.5 \mu \mathrm{m}, \mathrm{L}=100 \mathrm{~km}, \mathrm{P}_{\mathrm{p}}=0.5 \mathrm{~W}$

\begin{tabular}{|c|c|c|c|c|c|c|c|c|}
\hline$\lambda_{p}$ & $\alpha_{p}$ & Leff & $\alpha_{\mathrm{s}}$ & att & $\Delta \mathrm{k}_{\mathrm{ps}}$ & $\mathrm{g}_{\mathrm{rxt}}$ & $G$ & $\mathrm{~g}_{\mathrm{rxt}} \mathrm{Leff}_{\mathrm{eff}}$ \\
\hline 1.44 & 0.2456 & 17.62 & 0.1886 & -18.86 & 493 & 0.7726 & 38.76 & 13.613 \\
\hline 1.4553 & 0.2172 & 19.86 & 0.1886 & -18.86 & 420 & 0.8837 & 57.37 & 17.550 \\
\hline 1.48 & 0.2238 & 19.29 & 0.1886 & -18.86 & 305 & 0.4846 & 20.23 & 9.348 \\
\hline$\lambda_{p}$ & $Z_{\text {Fmax }}$ & $\mathrm{G}_{\text {Fmax }}$ & $\mathrm{Z}_{\mathrm{Bmin}}$ & $\mathrm{G}_{\mathrm{Bmin}}$ & $Z_{\text {Dmax }}$ & $\mathrm{G}_{\mathrm{Dmax}}$ & $Z_{D \min }$ & $\mathrm{G}_{\mathrm{Dmin}}$ \\
\hline 1.44 & 49.54 & 45.64 & 50.46 & -10.28 & 45.96 & 28.76 & 54.04 & 19.36 \\
\hline 1.4553 & 60.26 & 61.62 & 39.74 & -7.50 & - & - & - & - \\
\hline 1.48 & 45.31 & 27.66 & 54.69 & -11.14 & 35.96 & 10.53 & 64.04 & 9.70 \\
\hline
\end{tabular}

\section{Conclusion:}

The performance of Germania doped silica Raman amplifier fiber is affected by the optical fiber structure (core radius, a, ratio of Germania, $x_{1}$, and pump type) and the operating parameters (signal wavelength, $\lambda_{s}$, pump wavelength, $\lambda_{\mathrm{p}}$, and temperature, $\mathrm{T}$,).

The general formula for the Raman gain coefficient $\left(\mathrm{g}_{\mathrm{rxT}}\right)$ as a function of core radius $(\mathrm{a})$, Germania ratio $\left(\mathrm{x}_{1}\right)$, signal wavelength $\left(\lambda_{s}\right)$, pump wavelength $\left(\lambda_{\mathrm{p}}\right)$ and operating temperature $(\mathrm{T})$ is derived. The effect of $\mathrm{x}_{1}, \mathrm{~T}$ and $\lambda_{s}\left(\lambda_{p}\right)$ on the attenuation coefficient $\alpha_{s}\left(\alpha_{p}\right)$ is done. The final optical signal gain $(G)$ independent on the position of pump. The gain value decreases with temperature but it increases with $\mathrm{x}_{1}$,

The gain distribution through the longitudinal coupler length of dual pumps becomes the best than distributions of forward and back pumps. Additionally, the gain distribution becomes very best with the power of the two pumps of dual pump are equals. The effect of $\lambda_{\mathrm{s}}$ on the amplifier gain becomes very evident.

Magnitude of gain variation depends upon the product of Raman gain coefficient, effective amplifier length and the pump power. With $\mathrm{L}=100, \mathrm{P}_{\mathrm{p}}=1.0 \mathrm{~W}, \lambda \mathrm{p}=1.48 \mu \mathrm{m}, \mathrm{x}_{1}=0.03$, when the Germanna ratio increases from 0.03 to 0.05 , the gain $\mathrm{G}$ increases from $171 \%(\mathrm{~T}=253 \mathrm{~K})$ to $202 \%(\mathrm{~T}=333 \mathrm{~K})$ with $\lambda_{\mathrm{s}}=1.55 \mu \mathrm{m}$ while with $\lambda_{\mathrm{s}}=1.60 \mu \mathrm{m}$, the percentage becomes $173 \%(\mathrm{~T}=253)$ to $186 \%(\mathrm{~T}=333 \mathrm{~K})$.

Raman gain of an optimized bi-directionally pumped fiber Raman amplifier is studied. The gain decreases with increasing the fiber core radius (a). 


\section{References}

[1] S. Shameem and A. Sivasubramanian, "Performance Improvement of Gain in Distributed Raman Amplifier Using Forward and Backward Pumps” Springer Nature Singapore Pte Ltd. Pp.221-227, 2018

[2] Mohammed N. Islam, "Raman Amplifiers for Telecommunications" , IEEE Journal of selected topics in quantum electronics, Vol. 8, No. 3, pp. 548-559, May/June 2002

[3] Deben Lamon and JelleStuyvaert, "Raman amplification," univrsidade do porto, FEUP Faculdade de Engenharia , Anolectivo pp.4, 2007 - 2008

[4]Marcelo A. Soto and Fabrizio Di Pasquale ,” Distributed Raman Sensing “, Handbook of Optical Fibers pp 1-55| Cite as, First Online: 04 December 2017

https://link.springer.com/referenceworkentry/10.1007/978-981-10-1477-2_6-1 1 may at 2 AM

[5] ST. Davey, D.L. Williams, B.J. Ainslie, W.J.M. Rothwell and B. Wakefield, "Optical Gain Spectrum of $\mathrm{GeO}_{2}-\mathrm{SiO}_{2}$ Raman Fibre Amplifiers", IEE Proceedings, Vol. 136, Pt. J, No. 6, pp.301-306, Dec.1989.

[6] Govind P. Agrawil, "Fiber Optic Communication Systems," John Wiley \& Sons Inc. $3^{\text {ed }}$ edition, pp.33-37, 2002

[7] Mahmoud I. Abd-Alla and Fatma M. Aref M. Houssien," Improvement of the Performance of Advanced Local Area Optical Communication Networks by Reduction the Effects of the Propagation Problems," International Journal of Computer Science and Information Technologies (IJCSIT), Vol.1 (3), pp.147-157, 2010.

[8] Arwa H. Beshr1, Moustafa H. Aly1\# and A.K. AboulSeoud2," Amplified Spontaneous Emission Noise Power in Distributed Raman Amplifiers," International Journal of Scientific \& Engineering Research Volume 3, Issue 5, pp.1-5, May-2012 1 ISSN 2229-5518

[9] Fedor Mitschke," A Brief History of Fiber-Optic Soliton Transmission”, Springer Nature Singapore Pte Ltd. Pp.19, 2018

[10] Yuhong Kang, "Calculations and Measurements of Raman Gain Coefficients of Different Fiber Types", Thesis submitted to The Faculty of the Virginia Polytechnic Institute and State University in partially fulfillment of the requirements for the degree of Master of Science in Electrical Engineering Roger $\mathrm{H}$. Stolen, Chair, Ira Jacobs Ahmad Safaai-Jazi, December 9, 2002, Blacksburg, Virginia

[11] L.N. Binh, T.L huynh, S. Sargent and A. Kirpalani," Fiber Raman Amplification in Ultra-high Speed UltraLong-Haul Transmission: Gain Profile, Noises and Transmission Performance,” Department of Electrical and Computer Systems Engineering Technical Report MECSE-1-2007

[12] S. T. Davey, D. L. Williams, B. J. Ainsite , W. J. M. Rothwell and B. Wakefield ," Optical Gain Spectrum Of GeO2-SiO2 Raman fiber Amplifier,” IEEE proceding, Vol. 136, PL. J., No.6, pp.301-306, Dec. 1989

[13] ST. Davey, D.L. Williams, B.J. Ainslie, W.J.M. Rothwell and B. Wakefield," Optical gain spectrum of GeO2-SiO2 Raman fiber amplifiers," IEE PROCEEDINGS, Vol. 136, Pt. J, No. 6, pp.301-306, DECEMBER 1989

[14] Mohammed N. islam," Raman amplifiers for Telecommunications \& physical principles," Springer Verlag, New York, page 12, 2004

[15] Kjær, Rasmus; Jeppesen, Palle; Oxenløwe, Leif Katsuo; Pálsdóttir, Bera, "Raman amplification in optical communication systems,” Ph.D. thesis, Technical University of Denmark pp.10, 14, 20. June 2008.

[16] Kjær, Rasmus; Jeppesen, Palle; Oxenløwe, Leif Katsuo; Pálsdóttir, Bera, "Raman amplification in optical communication systems," Ph.D. thesis, Technical University of Denmark pp.10, 14, 20. June 2008.

[17] Clifford Headley Govind P. Agrawal, "Raman Amplification in Fiber Optical Communication Systems," Elsevier Academic Press, pp.40-46, 2005

[18] John D. Downie, Ming-Jun Li, and Sergejs Makovejs, "Single-Mode Fibers for High Speed and Long-Haul Transmission,” (C) Springer Nature Singapore Pte Ltd. Pp.18- 22, 2018, G.-D. Peng (ed.), Handbook of Optical Fibers,

[19] O. Frazão, C. Correia, M.T.M. Rocco Giraldi, M.B. Marques, H.M. Salgado, M.A.G. Martinez, J.C.W.A. Costa, A.P. Barbero and J.M. Baptista," Stimulated Raman Scattering and its Applications in Optical Communications and Optical Sensors, The Open Optics Journal, Vol.3, pp.1-11, 2009.

[20] Saimunur Rahman," An Introduction to Stimulated Raman Scattering and its Applications in optical fiber communications," International journal of Scientific footprints, 2(3) pp. 31-45, 2014

[21] D. B. M. Pereira, A. L. J. Teixeira, M. J. N. Lima, P. S. B. André, H. C. C. Fernandes, J. R. Ferreira, "Raman Amplifiers for Use in WDM Systems", REVISTA DO DETUA, VOL. 3, Nº 8, JANEIRO 2003

[22] J. Toulouse "Optical Nonlinearities in Fibers: Review, Recent Examples, and Systems Applications', J. of light wave Tech., Vol. 23, No. 11, pp.3625 - 3641, Nov. 2005 ,

[23] L.N. Binh, T.L huynh, S. Sargent and A. Kirpalani," Fiber Raman Amplification in Ultra-high Speed UltraLong-Haul Transmission: Gain Profile, Noises and Transmission Performance," Department of Electrical and Computer Systems Engineering Technical Report MECSE-1-2007

Technical Report Optical Communications and Applied Photonics Group Center for Telecommunications and Information Engineering. 
[24] Yuhong Kang, "Calculations and Measurements of Raman Gain Coefficients of Different Fiber Types", Thesis submitted to The Faculty of the Virginia Polytechnic Institute and State University in partially fulfillment of the requirements for the degree of Master of Science in Electrical Engineering Roger $\mathrm{H}$. Stolen, Chair, Ira Jacobs Ahmad Safaai-Jazi, December 9, 2002, Blacksburg, Virginia

\section{Appendix A: Refractive index of silica doped Germania}

The refractive indices of core (silica doped Germania, $\mathrm{n}_{1}$ ) and clad material (silica, $\left.\mathrm{n}_{2}\right)$ are functions of temperature $\left(\mathrm{T}^{\circ} \mathrm{K}\right)$ and the ratio of Germania $\left(\mathrm{x}_{1}\right)$ as defined in [7].

$$
\begin{aligned}
& n_{1}^{2}=1+\frac{a_{1 x t} \lambda^{2}}{\left(\lambda^{2}-b_{1 x t}^{2}\right)}+\frac{a_{2 x t} \lambda^{2}}{\left(\lambda^{2}-b_{2 x t}^{2}\right)}+\frac{a_{3 x t} \lambda^{2}}{\left(\lambda^{2}-b_{3 x t}^{2}\right)} \\
& n_{2}^{2}=1+\frac{a_{1 t} \lambda^{2}}{\left(\lambda^{2}-b_{1 t}^{2}\right)}+\frac{a_{2 t} \lambda^{2}}{\left(\lambda^{2}-b_{2 t}^{2}\right)}+\frac{a_{3 t} \lambda^{2}}{\left(\lambda^{2}-b_{3 t}^{2}\right)} \ldots
\end{aligned}
$$

where;

$\mathrm{a}_{1 \times t}=\left(\mathrm{a}_{10}+\mathrm{u}_{1} \mathrm{x}_{1}\right) \mathrm{ft}_{\mathrm{t} 1}, \quad \mathrm{a}_{2 \times t}=\left(\mathrm{a}_{20}+\mathrm{u}_{2} \mathrm{x}_{1}\right) \mathrm{f}_{\mathrm{t} 1}, \quad \mathrm{a}_{3 \times \mathrm{x}}=\left(\mathrm{a}_{30}+\mathrm{u}_{3} \mathrm{x}_{1}\right) \mathrm{f}_{\mathrm{t} 1}$,

$\mathrm{b}_{1 \mathrm{xt}}=\left(\mathrm{b}_{10}+\mathrm{v}_{1} \mathrm{x}_{1}\right) \mathrm{f}_{\mathrm{t} 2}, \quad \mathrm{~b}_{2 \times \mathrm{x}}=\left(\mathrm{b}_{20}+\mathrm{v}_{2} \mathrm{x}_{1}\right) \mathrm{f}_{\mathrm{t} 2}, \mathrm{~b}_{3 \times \mathrm{t}}=\left(\mathrm{b}_{30}+\mathrm{v}_{3} \mathrm{x}_{1}\right) \mathrm{f}_{\mathrm{t} 2}$

$\mathrm{a}_{10}=0.6961663, \mathrm{a}_{20}=0.4079426, \mathrm{a}_{30}=0.8974794, \mathrm{~b}_{10}=0.0684043, \mathrm{~b}_{20}=0.1162414, \mathrm{~b}_{30}=9.8961610$

$\mathrm{f}_{\mathrm{t} 1}=\mathrm{e}_{1}+\mathrm{e}_{2} \mathrm{~T}, \mathrm{f}_{\mathrm{t} 2}=\mathrm{T}_{0} / \mathrm{T}, \mathrm{e}_{1}=0.93721, \mathrm{e}_{2}=0.0002143, \mathrm{~T}_{0}=293{ }^{\circ} \mathrm{K}$,

$\mathrm{u}_{1}=0.1107001, \mathrm{u}_{2}=0.31021588, \mathrm{u}_{3}=-0.04331091, \mathrm{v}_{1}=0.000568306, \mathrm{v}_{2}=0.03772465, \mathrm{v}_{3}=1.94577$

$a_{1 t}, a_{2 t}, a_{t 3}, b_{1 t}, b_{2 t}$ and $b_{3 t}$ are defined by putting the value of $x 1=0$ through the parameters $a_{1 x t}, a_{2 x t}, a_{3 x t}, b_{1 x t}, b_{2 x t}$ and $b_{3 \times t}$ respectively.

\section{Appendix B Stimulated Raman scattering gain coefficient of pure silica $\left(\mathrm{g}_{\mathrm{R} 0}\right)$}

By using the published data [10] and by using the fitting curve technique, $\mathrm{g}_{\mathrm{R} 0}$ versus $\Delta \mathrm{k}_{\mathrm{ps}}$ is defined from Fig.B.1 as; For $\Delta \mathrm{k}_{\mathrm{ps}}=50$ to $200 \mathrm{~cm}^{-1} ; 10^{13} g_{R 0}=0.0237+0.0034 \Delta k_{p s}-2.385 * 10^{-5} \Delta k_{p s}^{2}+6.235 * 10^{-8} \Delta k_{p s}^{3}$

For $\Delta \mathrm{k}_{\mathrm{ps}}=201$ to $300 \mathrm{~cm}^{-1} ; 10^{13} g_{R 0}=-2.4733+0.03532 \Delta k_{p s}-0.0001537 \Delta k_{p s}^{2}+2.25925 * 10^{-7} \Delta k_{p s}^{3}$

For $\Delta \mathrm{kps}_{\mathrm{ps}}=301$ to $417 \mathrm{~cm}^{-1} ; 10^{13} g_{R 0}=-1.88+0.01145 \Delta k_{p s}-1.29 * 10^{-5} \quad \Delta k_{p s}^{2}$

For $\Delta \mathrm{k}_{\mathrm{ps}}=418$ to $440 \mathrm{~cm}^{-1} ; 10^{13} g_{R 0}=1.5565-0.002174 \Delta k_{p s}$

For $\Delta \mathrm{k}_{\mathrm{ps}}=441$ to $460 \mathrm{~cm}^{-1} ; 10^{13} g_{R 0}=-0.39+0.00223 \Delta k_{p s}$

For $\Delta \mathrm{k}_{\mathrm{ps}}=461$ to $535 \mathrm{~cm}^{-1} ; 10^{13} g_{R 0}=0.4787+0.001635 \Delta k_{p s}-2.745 * 10^{-6} \quad \Delta k_{p s}^{2}$

For $\Delta \mathrm{k}_{\mathrm{ps}}=536$ to $567 \mathrm{~cm}^{-1} ; 10^{13} g_{R 0}=7.7912-0.01353 \Delta k_{p s}$

For $\Delta \mathrm{k}_{\mathrm{ps}}=568$ to $600 \mathrm{~cm}^{-1} ; 10^{13} g_{R 0}=0.0341+0.0001515 \Delta k_{p s}$

Where, $\Delta k_{p s}=10000\left(\frac{1}{\lambda_{p}}-\frac{1}{\lambda_{s}}\right) \mathrm{cm}^{-1}\left\{\right.$ where, $\lambda_{\mathrm{p}}(\mu \mathrm{m})$ and $\left.\lambda_{\mathrm{s}}(\mu \mathrm{m})\right\}$

\section{Appendix C : Values of parameter $\mathrm{C}_{\mathrm{v}}$}

The values of parameter $C_{v}$ is defined by using the published data [24] which is shown in Fig.C.1 and by using the fitting curve technique, $C_{\mathrm{v}}$ versus $\Delta \mathrm{k}_{\mathrm{ps}}$ is defined as;

For $\Delta \mathrm{k}_{\mathrm{ps}}=70$ to $220 \mathrm{~cm}^{-1}: c_{v}=0.011$

For $\Delta \mathrm{k}_{\mathrm{ps}}=220$ to $350 \mathrm{~cm}^{-1}: c_{v}=0.08963-0.000688 \Delta k_{p s}+1.51786 * 10^{-6} \Delta k_{p s}^{2}$

For $\Delta \mathrm{k}_{\mathrm{ps}}=350$ to $430 \mathrm{~cm}^{-1}: c_{v}=-0.55117+0.002559 \Delta k_{p s^{-}} 2.53247 * 10^{-6} \Delta k_{p s}^{2}$

For $\Delta \mathrm{kps}_{\mathrm{ps}}=430$ to $500 \mathrm{~cm}^{-1}: c_{v}=-0.635875+0.003689 \Delta k_{p s}-4.70238 * 10^{-6} \Delta k_{p s}^{2}$

For $\Delta \mathrm{k}_{\mathrm{ps}}=500$ to $620 \mathrm{~cm}^{-1}: c_{v}=1.5979-0.008927 \Delta k_{p s}+1.718 * 10^{-5} \Delta k_{p s}^{2}-1.1162 * 10^{-8} \Delta k_{p s}^{3}$

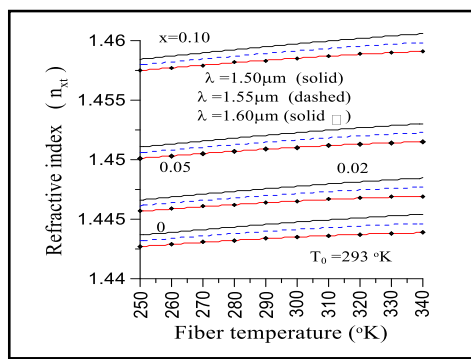

Fig.A.1 Refractive index $\left(\mathrm{n}_{\mathrm{xt}}\right)$

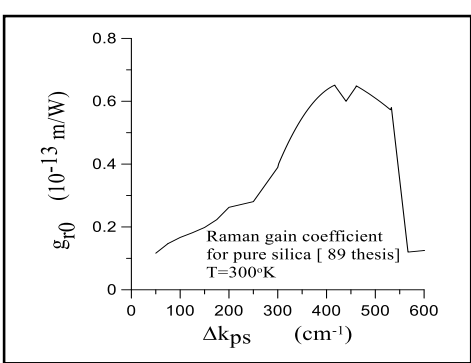

Fig.B.1:gR0 [10] Fig.C.1: Values of $\mathrm{C}_{\mathrm{v}}$ [24]

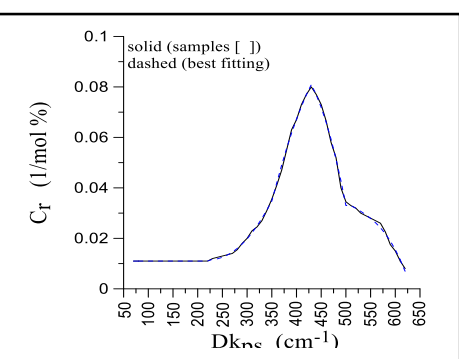

